Review

\title{
A Systematic Literature Review on Data and Information Required for Circular Manufacturing Strategies Adoption
}

\author{
Federica Acerbi $*$ (), Claudio Sassanelli $\mathbb{1}$, Sergio Terzi and Marco Taisch \\ Department of Management, Economics and Industrial Engineering, Politecnico di Milano, Via Lambruschini, \\ 4/B, 20156 Milan, Italy; claudio.sassanelli@polimi.it (C.S.); sergio.terzi@polimi.it (S.T.); \\ marco.taisch@polimi.it (M.T.) \\ * Correspondence: federica.acerbi@polimi.it
}

Citation: Acerbi, F.; Sassanelli, C.; Terzi, S.; Taisch, M. A Systematic Literature Review on Data and Information Required for Circular Manufacturing Strategies Adoption. Sustainability 2021, 13, 2047. https:// doi.org/10.3390/su13042047

Academic Editor: Antonella Petrillo Received: 29 December 2020

Accepted: 5 February 2021

Published: 14 February 2021

Publisher's Note: MDPI stays neutral with regard to jurisdictional claims in published maps and institutional affiliations.

Copyright: (c) 2021 by the authors. Licensee MDPI, Basel, Switzerland. This article is an open access article distributed under the terms and conditions of the Creative Commons Attribution (CC BY) license (https:// creativecommons.org/licenses/by/ $4.0 /)$.

\begin{abstract}
In the extant literature, circular economy (CE) is considered a driver for sustainable development of the manufacturing sector, being it an industrial paradigm aiming at regenerating resources. CE is transferred to manufacturing companies through the adoption of different Circular Manufacturing (CM) strategies (e.g., recycling, remanufacturing, etc.). Nowadays, manufacturers are struggling to implement these strategies to limit their resource consumption and pollution generation. To enable their adoption, the extant literature unveiled the importance to control along the entire value chain different types of resource flows (i.e., material, energy, and information). Nevertheless, while for material and energy management some advancements were achieved, information management and sharing remains one of the major barriers in adopting these strategies. The present work, through a systematic literature review, aims to identify the relevant information and data required to support the manufacturer's decision process in adopting and managing the different CM strategies to pursue the transition towards CM. Furthermore, based on the results obtained, this research proposes a theoretical framework. It elucidates the four main areas to be managed by manufacturers in adopting $\mathrm{CM}$ strategies and it provides to the manufacturer an overview of what should be updated and upgraded inside the company to embrace CM strategies.
\end{abstract}

Keywords: circular economy; circular manufacturing; theoretical framework; information and data management; systematic literature review; industrial sustainability

\section{Introduction}

The last century has been characterised by an immoderate resource consumption trend followed by an uncontrollable increase of $\mathrm{CO}_{2}$ emissions, which, if not stopped, might lead to planet collapse. Research dating back to the 1960s perceived this issue as a great problem to be addressed by society as a whole [1]. Therefore, while the concept behind sustainability is quite old, the term "sustainability" started to appear in the literature in the late 1970s [2]. Moreover, considering the importance of these issues, policymakers started promoting what is called "sustainable development" [3], grounded on environmental, economic, and social pillars [4]. Manufacturers are compelled to implement sustainable strategies to be taken on [5] to decouple their economic growth from resources consumption and maintain their high competitive advantage without creating negative externalities during their manufacturing activities. Among the possible solutions, the adoption of circular economy (CE), an industrial economy aiming at regenerating and restoring resources [6], started to be encouraged by policymakers worldwide, being it considered a great driver for manufacturing sustainability. The European Commission confirmed its position with the last recent update of the action plan [7]. In line with these actions, countries worldwide, as China [8], Australia [9] and USA [10] are promoting circular initiatives.

CE aims to extend the product lifecycle by slowing, narrowing, and closing resources loops [11] through biological, technical, and information cycles [12], and takes the name of Circular Manufacturing (CM) when applied in manufacturing companies [13]. CM is 
defined as "the concurrent adoption of different CM strategies, which enable to reduce resources consumption, to extend resources lifecycles and to close the resources loops, by relying on manufacturers' internal and external activities that are shaped in order to meet stakeholders' needs" (p.11) [13]. More precisely, circular design, disassembly, remanufacture, reuse, recycle, servitization, cleaner production, resource efficiency, waste management, industrial symbiosis, and closed-loop supply chain and reverse logistics represent the $\mathrm{CM}$ strategies identified in the systematic literature review (SLR) performed by [13]. These strategies promote the alignment of the manufacturing sector with the sustainable development goals [14] and require a huge transformation from a socio-technical point of view [15]. This transformation needs support by intermediaries like policymakers and requires changes in the relations among actors involved, and their links with infrastructures, technologies, and contexts of application [16]. As reported in recently published reviews, the diffusion of $C E$ in manufacturing is limited by several barriers. Taking as a representative sample those provided by Tura et al. (2019), and Ritzèn and Sandstrom (2017), these barriers could be economic and financial (due to a limited financial capability and support for companies), social (due to a lack of awareness among consumers), institutional (caused by the limited government support), technological and informational (caused by the reduced sharing of information and knowledge, organizational and attitudinal due to a silos approach and the fear of change), and last, along the supply chain, operational (due to a lack of support by the network and limited creations of appropriate partnerships) $[17,18]$. Most of the research agrees on these barriers in adopting CM, but among all, information management and sharing remains one of the major ones, causing a lack of support for the decision-making process requiring data and information standardisation [19]. Shortage of data flows generally represents a big issue for companies leading organizations to a silos setting [20]. Indeed, it would limit the potential of knowledge management (KM) practices in supporting a structured and aligned internal organization. To report an example specifically to $\mathrm{CM}$, lack of data is detrimental for the selection of the right partner with whom to exchange resources in an industrial symbiosis network [19]. In addition, lack of data could undermine the right choice regarding the most appropriate strategy required to extend the lifecycle of the resources under analysis. This choice can be facilitated with the collection of data especially from end-of-life phases of the product lifecycle with the aim of improving the product design of next product generations [21]. Therefore, the sharing and usage of data, both internally and externally, will empower companies in enhancing their organizational and structural capabilities in extending the resources lifecycle. A preliminary and essential step to overcome this challenge is to identify which are the necessary data and information to be gathered, shared and managed [22]. Indeed, the complexity of this transition, determined also by the involvement of different stakeholders impacting of the decision-making process of manufacturers [23], requires us to gather data and information along each stage of the product lifecycle to pursue circular paths [24]. The gathering of data and information implies their management, by employing KM principles which consist of systematically discovering, acquiring, capturing, sharing and using productive knowledge in a cost-effective way to improve firms' and organizations' performances [25]. As proposed in the literature, KM can be based on a three-level framework: (i) knowledge requirements, (ii) knowledge reuse, and (ii) knowledge sharing [26].

Through an SLR, this work aims to put the basis to facilitate manufacturers' decisionmaking process in $\mathrm{CM}$ strategies adoption, by identifying and classifying all the relevant information and data required to pursue the transition in an efficient and structured way, concerning each CM strategy. In addition, to concretely provide exploitable support to manufacturers, the supporting technologies and tools, through which data and information are gathered and managed to create exploitable knowledge, are investigated. Therefore, although the extant literature presents a plethora of SLR investigating for instance how the technological advancements can support the establishment of circular systems [27], or what characterises the adoption of CE in manufacturing [13], or how a specific strategy is structured [28], until now a review aimed at clarifying in a structured and extensive 
way how to overcome the information management barrier issue is still missing; thus, it is essential to investigate the required data and information to be collected to adopt each $\mathrm{CM}$ strategy and the related supporting technologies.

Therefore, the objective of the present contribution is to overcome this scientific gap and to provide to practitioners a tool highlighting the main data and information required to design and manage circular systems through the adoption of different CM strategies based on data exploitation. To achieve the paper objectives, the research questions (RQ) addressed are the following: RQ1: "What data and information need to be gathered to support the decision-making process of manufacturers in CM adoption?" RQ2: "What are the tools (technologies or traditional tools) necessary to exploit data and information in CM?"

The article is structured as follows. Section 2 provides the description of the research methodology adopted. In Section 3, the literature review results show the state of the art regarding data, information and technologies supporting manufacturing companies' $\mathrm{CM}$ transition focusing the attention of each CM strategy. In Section 4, a theoretical framework is proposed discussing the literature review results. In Section 5, scientific, managerial and policymakers' implications are elucidated, opening the way to future research.

\section{Materials and Methods}

Considering information shortage as a barrier to adopt $\mathrm{CM}$ strategies, and the need to streamline information and data management under a circular perspective, this paper operates an SLR [29] to detect in a structured way the data and information required to enable manufacturing companies to embrace CM. Different contributions investigated in a systematic way the theory behind $\mathrm{CE}$, e.g., to define the $\mathrm{CE}$ concept [30] or to explore the state of the art of academic research within the CE domain [31]. Despite the need to strengthen information flow, the systematic analysis of the data and information required in CM to support the decision-making process has not been performed yet. Indeed, so far, few studies supporting the decision-making process focused on one single CM strategy (e.g., on remanufacture [32]) have been conducted. Therefore, out of all the past reviews, the peculiarity of this contribution is the investigation of the data required to approach and manage each single CM strategy, considering those identified in Acerbi and Taisch (2020) (i.e., circular design, disassembly, remanufacture, recycle, reuse, servitization, cleaner production, resource efficiency, waste management, industrial symbiosis, and closed-loop supply chain) [13]. This analysis enables us to understand what relevant data, information and technologies are required for the adoption of each CM strategy, to create awareness and give a basic instrument, at least from an informational perspective, to the manufacturers in charge of the transition.

"Scopus" was used as scientific database for this review, being it the most diffused one for industrial engineering and having a broader coverage [33]. "Scopus" was queried using the following keywords: TITLE-ABS-KEY (("knowledge" OR "information" OR "data") AND "management") AND ("circular economy" OR "close-loop") AND ("Remanufacturing" OR "Recycling" OR “Reuse" OR "Reduce" OR “Redesign" OR “Recover") AND "manufacturing" AND ("digital technolog*" OR "Industry 4.0" OR "i4.0" OR "information technolog*" OR "platform*" OR "digital platform*" OR "authoring tool*" OR "PLM"). These keywords were defined after a random screening process in the extant scientific literature regarding contributions dealing with data and information in CM, selecting keywords coherent with the terminology adopted in the extant scientific literature. Nevertheless, the string of keywords enabled to partially limit the panel of papers within the boundaries of the research interest, and therefore other eligibility criteria were added. Only English written documents were selected, to include the latest global studies, without any restriction on timeframe and publication sources. A screening process was performed leveraging on three main criteria to discard out-of-topic papers, thus not dealing with data and information in $\mathrm{CM}$ : 
- Papers not focused on CM (these account for the $47 \%$ of the papers discarded, that in absolute numbers correspond to a reduction of 35 papers from the sample of Englishwritten documents);

- Papers not dealing with data and information for CM (these account for the $48 \%$ of the papers discarded, that in absolute numbers correspond to a reduction of 36 papers from the sample of English-written documents);

- Papers not focused on the manufacturing sector (these account for the $5 \%$ of the papers discarded, that in absolute numbers correspond to a reduction of 4 papers from the sample of English-written documents).

Indeed, starting from 178 documents identified through the keyword query, out of which 163 written in English, only 88 were selected for the review, as reported in Figure 1.

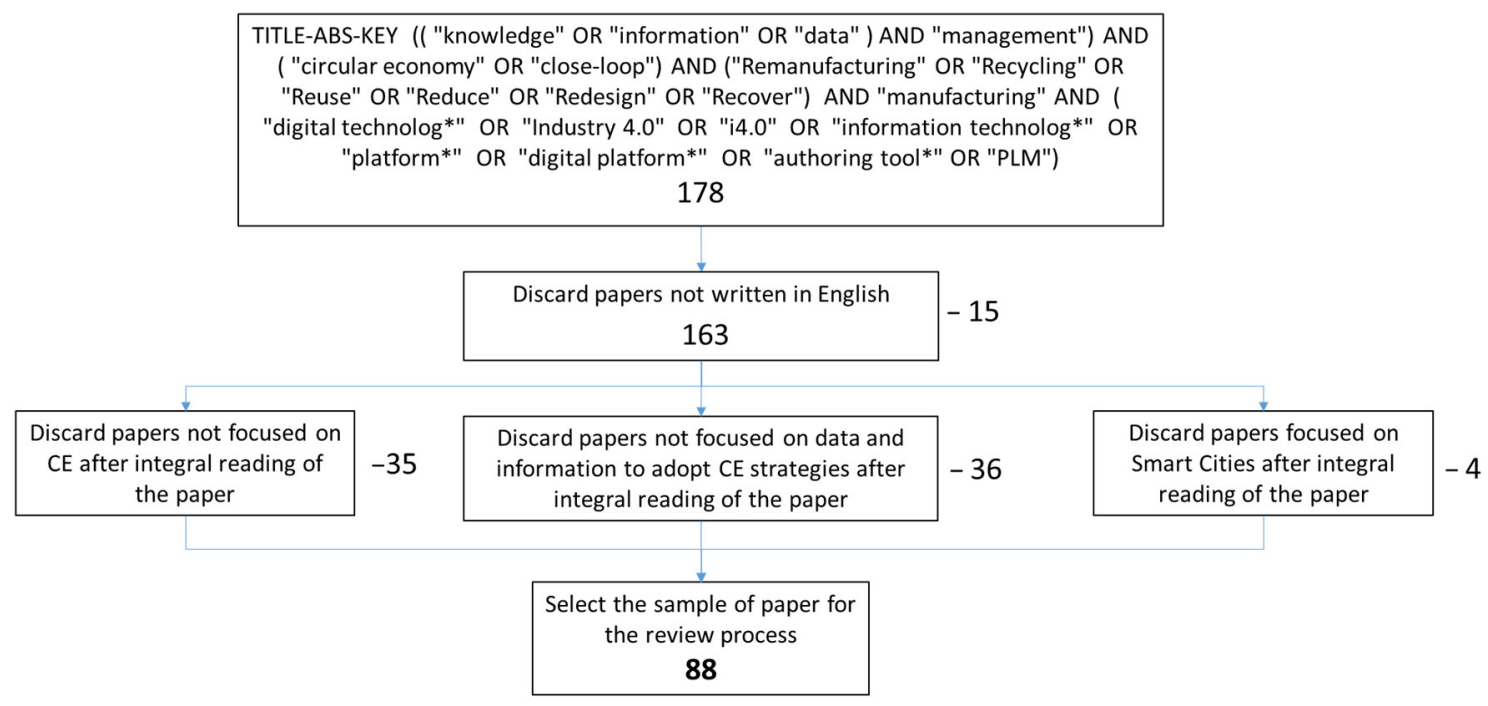

Figure 1. Paper screening process.

Using the SLIP method (which helps to Sort, Label, Integrate and Prioritize key concepts) [34], recently employed in a SLR in the CE context [35], the set of 88 documents has been analysed to detect and group the categories of the analysis. Specifically, for each CM strategy, the data and information were clustered into three categories: product, processes, and management. A fourth category, technologies and tools, was included in the analysis to show what tools can be adopted for data and information gathering and management.

\section{Literature Review Results: Data and Information in CM}

This section is divided into two main sub-sections: "Descriptive statistics" and "Data and Information required for CM". "Descriptive statistics" gives a general overview of quantitative results emerged from the sample of papers selected. "Data and Information required for $\mathrm{CM}^{\prime \prime}$ is focused on the narrative review of the papers selected for the analysis.

\subsection{Descriptive Statistics}

Observing the sample of selected papers, the top ten journals where these contributions have been published are reported in Figure 2. In particular, the number of publications in Journal of Cleaner Production, Sustainability (Switzerland) and Resources, Conservation and Recycling evidently overcome the rates of the others. 


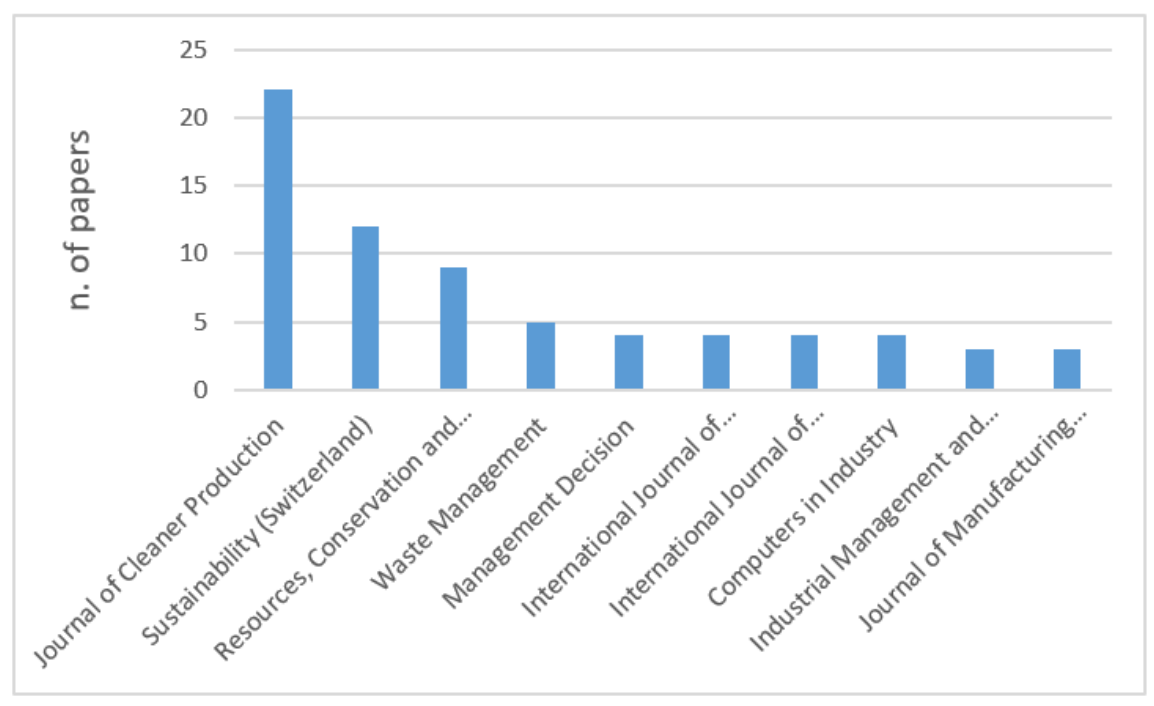

Figure 2. Top ten journal.

Some of the contributions were focused on specific manufacturing industries and the related statistics are reported in Figure 3. Electronic and Construction industries emerged to be the most advanced in $\mathrm{CE}$, especially Electronic which is compelling to manage Waste Electrical and Electronic Equipment (WEEE) from years. Nevertheless, the majority of the papers did not provide indications regarding the specific manufacturing industry (see Figure 4).

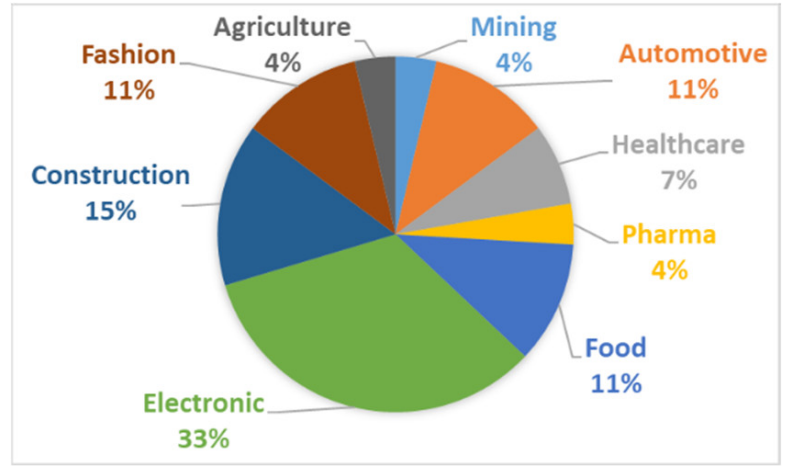

Figure 3. Paper statistics per industrial manufacturing industries.

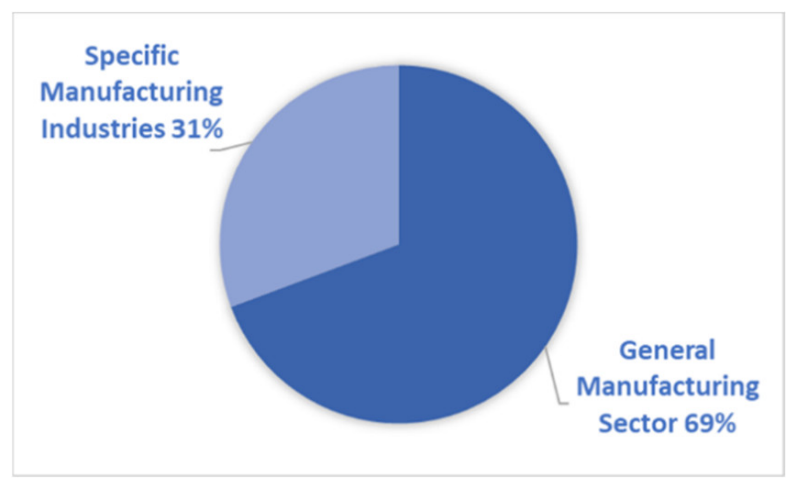

Figure 4. Paper statistics per manufacturing sector specificity.

Last, the contributions were clustered according to the CM strategy addressed, to evaluate the spectrum of strategies tackled and the number of papers focused on each strategy. 
In some cases, more than one strategy has been considered in a single document analysed (see Figure 5).

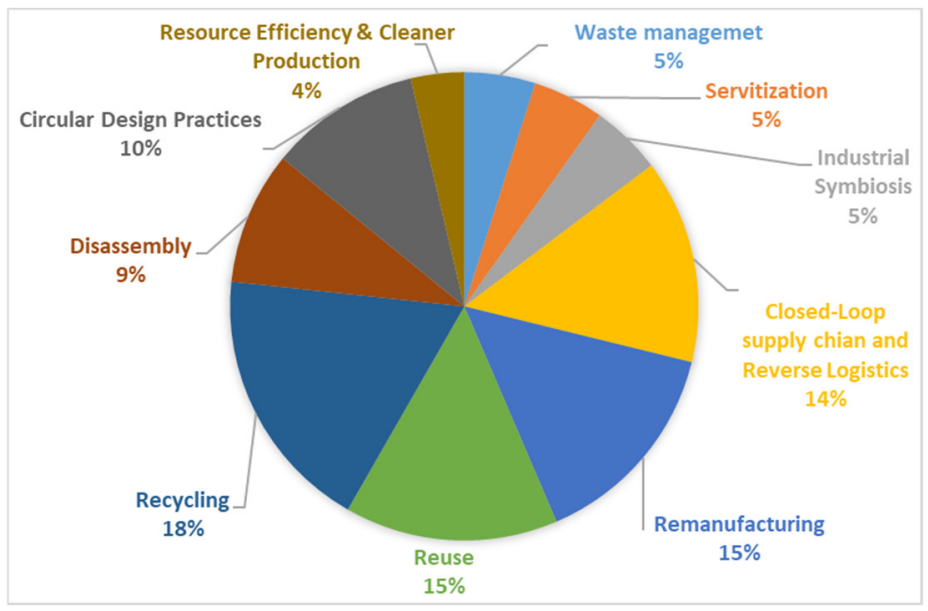

Figure 5. Paper statistics per CM strategy investigated in the paper.

\subsection{Data and Information Required for $C M$}

In this section, through the SLR, for each CM strategy, data and information are detected and clustered according to the three categories (i.e., product, process, management) and supportive technologies and tools are identified based on the SLIP method.

\subsubsection{Circular Design}

Circular design strategy is adopted for example by Fairphone to create modular and sustainable smartphones which can be achievable only if data regarding product characteristics and disassembly sequencing are gathered [36]. More precisely, Fairphone ensures the extension of their products lifecycle by gathering data during the design stage to start design the product to be easily repairable and flexible, to then improve these characteristics relying on consumers' behaviours data.

As also evident from this case, the decisions taken at the design stage, thus at the Beginning of Life (BoL), are the most important ones since they influence the potential environmental impacts that a product might generate during its lifecycle [37]. Decisions like the selection of the product material composition and the type of manufacturing processes, which strongly influence the rate of material or energy input per unit of product, gain a prominent position [37]. Moreover, the considerations regarding energy consumption cannot be limited only to product production, but required to be extended also over the product usage [38]. The materials selected must respect the sustainable requirements in terms of composition to avoid harmful materials, but also transportation modes to avoid pollution generation during the material delivery [39]. Besides the material, other information empower product circularity, among which the definition of product functionalities, estimation of disassembly tasks time and costs [40], product architecture, function, geometry, materials mix (weight and type), components specifications and assembly instruction [41]. To extend the product lifecycle, it is required to ensure, through product design, its maintainability, reparability, durability and the correct disposal [21]. The correct disposal is also influenced by customers' behaviours, which indeed need to be involved to ensure product circularity. Information such as product cost and customers' requirements complexity must be gathered [42]. This might require new managerial procedures and documentation which influence the traditional customers' management. Indeed, the influence of external stakeholders generates managerial implications during the transition. Other information to be gathered regards supply chain stakeholders' location, distribution model, retail prices, product demand, users' preferences. Moreover, the product must be designed to avoid its hibernation, by establishing recovery plans [43], and to keep high the possibility to 
extend its lifecycle, services to maintain product and production processes in use must be considered [44]. This can be done through maintenance or repairing activities that, if performed on internal physical assets, would foster the availability and the reliability of machinery and equipment, by also increasing the levels of safety [45] and product quality. Last, information costs regarding the planning (e.g., product requirements, finalization, materials), concept (e.g., reuse possibility), design (e.g., standardization, reusable parts), source (e.g., make or buy decisions, material procurement, supplier selection), manufacturing (e.g., process tooling, operational planning), launch (e.g., warranty analysis, predictive maintenance services), service (e.g., recycling, refurbishments) need to be estimated [46].

Regarding Circular Design strategy, the technologies and documentation usable to easily gather data are Bill Of Material (BOM), Product Life Cycle Management System (PLM), Sensors, Manufacturing Execution System (MES) and Enterprise Resource Planning (ERP) [47]. To use these data, visual analytics tools [41] and CAD 3D [38] can be implemented.

To summarise, linking these findings with RQ1 and RQ2, manufacturers embracing this strategy are recommended to gather data regarding product initial characteristics, functionalities and potentialities for their lifecycle extension. This information must be kept available until the product EoL to facilitate its management in terms of maintenance and recovery. It is important to select suppliers allowing that this can happen, and some peculiar relationships can be established with consumers thanks to the introduction for instance of warranty programs. Although external actors are relevant, technologies to be adopted for this strategy are necessary mainly for the internal sharing of data allowing first an internal alignment.

These results are summarised in Table 1.

Table 1. Circular design adoption data, information and technologies/tools.

\begin{tabular}{|c|c|c|c|}
\hline \multicolumn{4}{|c|}{$[21,37-39,41-43,45-48]$} \\
\hline Product & Process & Managerial & Technology/Tools \\
\hline $\begin{array}{l}\text { - Product Functionalities, } \\
\text { - } \text { Product Features, } \\
\text { - } \text { Product Architecture, } \\
\text { - } \text { Product Geometry, } \\
\text { - } \text { Material Mix } \\
\text { (weight and type), } \\
\text { - } \quad \text { Components } \\
\quad \text { Specifications, } \\
\text { - } \text { Assembly Instruction, } \\
\text { - } \text { Reuse Possibility, } \\
\text { - } \text { Overall Costs, } \\
\text { - } \text { Users preferences and } \\
\quad \text { requirements, } \\
\text { - } \text { Reparability, } \\
\text { - } \text { Durability, } \\
\text { - Maintainability, } \\
\text { - } \text { Modularity, } \\
\text { - Joints }\end{array}$ & 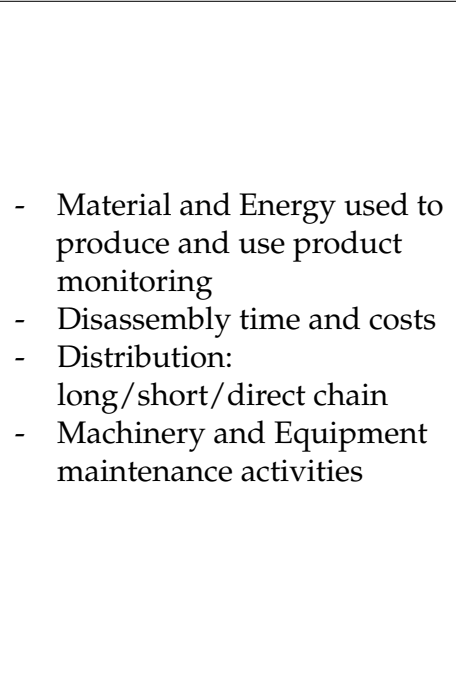 & $\begin{array}{ll}\text { - } & \text { Warranty programs } \\
\text { - } & \text { Maintenance service } \\
\text { - } & \text { Material } \\
& \text { Procurement } \\
\text { - } & \text { Supplier selection } \\
\text { - } & \text { Leasing agreement } \\
\text { - } & \text { Take back service }\end{array}$ & $\begin{array}{ll}\text { - } & \text { Visual Analytical Tools } \\
\text { - } & \text { CAD 3D } \\
\text { - } & \text { BOM } \\
\text { - } & \text { PLM } \\
\text { - } & \text { Sensors } \\
\text { - } & \text { MES } \\
\text { - } & \text { ERP }\end{array}$ \\
\hline
\end{tabular}

\subsubsection{Disassembly}

The disassembly strategy adoption highly facilitates the implementation of all the other CM strategies characterising the product EoL (e.g., remanufacture, waste management, etc.). A concrete example is given by the smartphones produced by Fairphone which are easily disassembled to ensure their circularity which is possible also thanks to an accurate data gathering at product EoL feeding the BoL with extensive data [36]. Regarding this strategy, Marconi et al. (2017) proposed quantitative measures to be considered during the disassembling process, that regard the disassembly depth, time, and costs. The first one 
is reflected in the number of operations to reach a target component; the second regards the time spent to reach it, and the third one regards the cost, in terms of both labour and tools, to disassemble it.

To summarise, linking these findings with RQ1 and RQ2, manufacturers embracing this strategy need to pay attention mainly on data and information regarding the type of tasks to disassemble a product and the time required, and need to invest in disassembling technologies to facilitate human work.

The results are summarised Table 2 .

Table 2. Disassembly adoption data, information and technologies/tools.

\begin{tabular}{|c|c|c|c|}
\hline \multicolumn{4}{|c|}{$[21,49,50]$} \\
\hline Product & Process & Managerial & Technology/Tools \\
\hline $\begin{array}{l}\text { - } \text { Product disassembly possibility } \\
\text { - Product criticalities evaluation } \\
\text { - } \text { Components substitution } \\
\text { possibility }\end{array}$ & $\begin{array}{l}\text { - Number of operations to reach a } \\
\text { target component } \\
\text { - } \quad \text { Time spent to reach a target component } \\
\text { - Labour and tools cost to reach a target } \\
\text { component } \\
\text { - Maintenance activities knowledge }\end{array}$ & - & 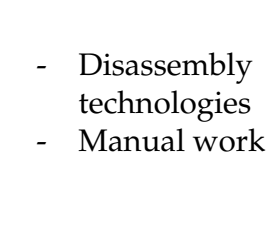 \\
\hline
\end{tabular}

\subsubsection{Recycle}

Relight (2020), operating in the recycling of electronics, is a typical example of companies adopting the recycle strategy [51]. The company has to gather information regarding waste characteristics in order to ensure the right treatment path. In accordance with that, the recycling strategy requires product analysis to evaluate whether it is possible its recyclability [52]. In case it would not be possible to select an external "recycling partner", the manufacturer itself requires us to perform a self-assessment to evaluate the company's level of sustainability to perform a recycling process. This evaluation influences the decision-making process of the manufacturer needing specific information covering all the TBL principles [53]:

1. economic: need to evaluate the operation costs per unit, the product quality utility and value, the technical level and the profitability;

2. environmental: the evaluation is on resource consumption efficiency, pollution production, energy efficiency, environmental management system, environment equipment, and facilities;

3. social: the focus is on employee turnover rate, customer satisfaction, brand reputation, and local communities influence are evaluated.

For each sustainable principle, product factors (e.g., product value), processes factors (e.g., energy consumption), managerial factors (e.g., brand reputation), and technologies (e.g., environmental equipment) are taken into account.

Wrapping up, bonding these findings with RQ1 and RQ2, manufacturers embracing this strategy are recommended to gather data especially on product composition to evaluate whether, and in case, which materials can be recycled to then decide how to treat them for instance for a possible upcycling. Thus, an analytical analysis of the treatment has to be performed and process data must be collected to evaluate the social, economic and environmental impacts. Regarding the required technologies, they need to invest in specific advanced technologies, like recycling robots, to be efficient in embracing this strategy, and in environmental management system to monitor materials environmental impacts.

The results are reported in Table 3. 
Table 3. Recycle adoption data, information and technologies/tools.

\begin{tabular}{|c|c|c|c|}
\hline \multicolumn{4}{|c|}{$[50,52,53]$} \\
\hline Product & Process & Managerial & Technology/Tools \\
\hline $\begin{array}{l}\text { - Recyclable Materials } \\
\text { and Components, } \\
\text { - Quality utility value, }\end{array}$ & $\begin{array}{ll}\text { - } & \text { Operation cost per unit } \\
\text { - } & \text { Technique level } \\
\text { - } & \text { Profitability } \\
\text { - } & \text { Resource consumption } \\
& \text { efficiency, } \\
\text { - } & \text { Pollution production } \\
\text { - } & \text { Energy efficiency }\end{array}$ & $\begin{array}{ll}\text { - } & \text { Best recycling partner } \\
& \text { selection or } \\
& \text { self-assessment } \\
\text { - } & \text { Employee turnover rate } \\
\text { - } & \text { Brand reputation, } \\
\text { - } & \text { Local communities } \\
& \text { influence } \\
\text { - } & \text { Recycled product } \\
\text { customer satisfaction }\end{array}$ & $\begin{array}{ll}\text { - } & \text { Environmental } \\
\text { management system } \\
\text { - } & \text { Environmental } \\
& \text { equipment and facilities } \\
\text { - } & \text { Recycling robots }\end{array}$ \\
\hline
\end{tabular}

\subsubsection{Remanufacture}

Remanufacture strategy is enacted for instance by America's remanufacturing co. (ARC) that bases its business model in ensuring to give the original quality level and characteristics to a turned back product [54]. ARC adopts advanced technologies to ensure to treat appropriately the product to be remanufactured according to the product conditions and they monitor the time and quality of turned back products. The remanufacturing strategy is characterized by a process based on different activities, which usually are: disassembly, cleaning, inspection, sorting, reconditioning or replacement, reassembly, and testing [55]. A remanufacturing process must satisfy some requirements to be introduced, for example, the components of the remanufactured product, including both collection and remanufacturing process costs, must cost less than the new ones. Moreover, to make valuable the introduction of the remanufacturing strategy, the manufacturer needs to introduce customer-oriented operations, by deploying adequate services, to take the benefits of an enlarging green market. This also implies that putting in place efficient core acquisition models to manage returned units and components, to appropriately plan remanufacturing processes, and to define the personnel involved would be beneficial. Therefore, regarding the returned products, the remanufacturer must gather specific information such as the product conditions, affected by consumers' usage, and the market demand; even though the level of uncertainties regarding the quality, quantity and time of returned products remains one of the major barriers [56]. On the product side, other information to be gathered regard the product type, model, original manufacturer, property (e.g., battery type) and the components; but also the localization, the amount of Work in Progress (WIP) to be remanufactured, the production plan, the resource status, the scheduling, the remanufacturing activities required for each product type (e.g., assembly, disassembly, inspection) and the related resources to perform these activities [57]. Indeed, returned products are characterized by different status and thus, during the inspection, according to the legislation and the conditions, specific processes are defined for each returned product. The MES on the shopfloor might support the gathering of these data. Indeed, this tool enables us to collect historical data to exploit the simulation benefits, extremely relevant in a context characterised by high uncertainty as returned products. Simulation supports the decision process by simulating real-time different scenarios and increasing the flexibility level of the company. Moreover, other technologies can be introduced, such as high levels of automation, advanced decision support tools based on data analytics, distributed data gathering, and cyber-physical systems to trace information to have them always available. Last, there must be a high level of safety and ergonomics conditions for humans working on the shopfloor [58].

To summarise, linking these findings with RQ1 and RQ2, manufacturers embracing this strategy are recommended to first gather data on product conditions which help in deciding which activities are required to remanufacture it. Then, an analysis regarding the costs and time to remanufacture the product must be performed to balance the activities scheduling, bearing in mind the technologies available to be adopted. Therefore, 
investments in advanced remanufacturing technologies linked to decision-support systems are suggested to be done. More in details, decision-support systems can be linked to monitoring systems allowing to keep track of product conditions and design characteristics to evaluate the best remanufacturing option.

The results are reported in Table 4.

Table 4. Remanufacture adoption data, information and technologies/tools.

\begin{tabular}{|c|c|c|c|}
\hline \multicolumn{4}{|c|}{$[49,50,55-58]$} \\
\hline Product & Process & Managerial & Technology/Tools \\
\hline $\begin{array}{ll}\text { - } & \text { Product conditions } \\
\text { - } & \text { Market requirements } \\
\text { - } & \text { Product type } \\
\text { - } & \text { Product model } \\
\text { - } & \text { Propriety } \\
& \text { (e.g., battery type) } \\
\text { - } & \text { Components } \\
\text { - } & \text { Components } \\
\text { manufacturer } \\
\text { information }\end{array}$ & 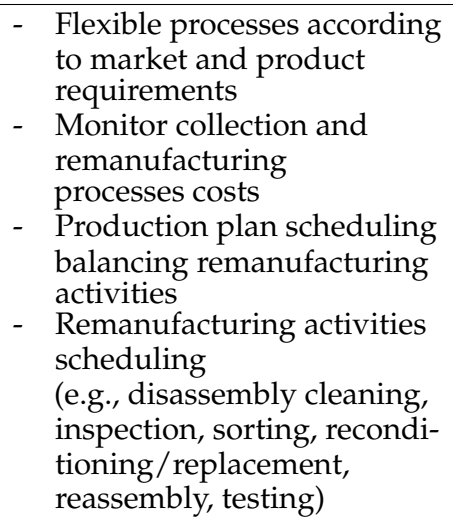 & $\begin{array}{l}\text { - Safety and ergonomics } \\
\text { condition for workers } \\
\text { - } \text { Planning of } \\
\text { remanufacturing } \\
\text { processes } \\
\text { - } \text { Monitor time, quantity } \\
\text { and quality of } \\
\text { returned products } \\
\text { - Monitor resources status }\end{array}$ & $\begin{array}{l}\text { - Remanufacturing } \\
\text { technologies with } \\
\text { advance } \\
\text { automation levels } \\
\text { - Tracking technologies to } \\
\text { trace information } \\
\text { - Decision support tools } \\
\text { based on data analytics } \\
\text { tools, distributed data } \\
\text { gathering and } \\
\text { cyber-physical systems } \\
\text { - Simulations tools } \\
\text { - MES on the shopfloor }\end{array}$ \\
\hline
\end{tabular}

\subsubsection{Reuse}

The reuse strategy is becoming widely diffused to encounter circular principles, as the case of Lush that sells reusable packaging, which can be reused only if their characteristics are still functional for the object purpose [59]. Therefore, reuse, as CM strategy, is enabled only in case there is an adequate product EoL management. On one side, this must be supported by managerial factors such as the right marketing activities to empower customers demand and make them aware of the benefits of turning the products back, but also through the monitoring of the legislation respectfulness. Moreover, to put in place an appropriate reuse strategy, the company has to monitor collection and transportation activities and related costs [60].

To summarise, linking these findings with RQ1 and RQ2, manufacturers embracing this strategy are recommended to gather data especially regarding the product functionalities and their location to ensure the convenience to reuse the product. Moreover, the most important thing remains the possibility to make reusable products which is reflected in the available regulations and consumers' awareness. No specific technologies are required for this strategy.

The results are summarised in Table 5.

Table 5. Reuse adoption data, information and technologies/tools.

\begin{tabular}{clll}
\hline & & [60] & \\
\hline Product & \multicolumn{1}{c}{ Process } & Managerial \\
\hline & & & Technology/Tools \\
\hline & - Product functionalities & - & Collection costs \\
& - & Supply costs & Legislation respectfulness \\
\hline
\end{tabular}

\subsubsection{Waste Management}

Another CM strategy adoptable by manufacturers is waste management. A concrete example of the adoption of this strategy is Greentronics (2020) which treats electronic waste after having checked for instance the type of waste, the possible hazardous substances present in the waste to evaluate how to treat them [61]. Before deciding whether to dis- 
pose or reprocess a product, there are different activities to be performed. More precisely, the activities are collection, sorting, disassembly, and data analytics regarding material type and weight, material flows quality, mass and volume [62] and the amount of waste reused [63]. In case the company deals with more peculiar and hazardous waste, such as batteries, besides the data concerning battery weight and waste collection centres location, more detailed data, like raw material composition per battery, are gathered [64]. A waste management strategy can be put in place also in case of product deletion which choice has huge impacts on operations, end-users, financials, and supply chain, due to the fact that the inventory of this product becomes obsolete. Therefore, other information is required such as: product type, product components, component materials type, components materials sourcing, product lifecycle stage, product quality, product circularity level, product location in the supply chain, internal storage capacity, end-user consumption and delivery modes [65]. Concerning the management category, from the Chinese experience, it has been suggested to create alliances among firms to establish unified collection channels modes, introduce platforms usable internally and with third parties [66].

From a technological point of view, all these activities can be supported by I4.0 technologies such as smart bins with sensors to detect and analyse material and waste, selfautomated vehicles and containers, methods to automatically analyse images. For sorting and disassembly, different types of robots can be used [62]. For data analytics on waste management, sensors, blockchain, deep learning techniques, multivariate model equation and Building Information Modelling (BIM) are suggested to be used [65]. Last, predictive models can be introduced to facilitate waste management [67].

To summarise, linking these findings with RQ1 and RQ2, manufacturers embracing this strategy are recommended to gather data regarding waste type and quantity to evaluate if it can be partially reused after specific treatments and whether are present hazardous substances to evaluate how to manage them to avoid negative impacts. For the sorting of waste, sensorized robotics empowered by big data analytics are suggested to be considered for future investments. In addition, considering also the importance to track the localisation of waste, in the near future blockchain can become the right means towards trusted tracking of resources.

The results are reported in Table 6.

Table 6. Waste Management adoption data, information and technologies/tools.

\begin{tabular}{|c|c|c|c|}
\hline \multicolumn{4}{|c|}{ [62-72] } \\
\hline Product & Process & Managerial & Technology/Tools \\
\hline $\begin{array}{l}\text { Product components } \\
\text { Product materials } \\
\text { composition, } \\
\text { Product material quality } \\
\text { Raw material composition } \\
\text { Raw material regeneration, } \\
\text { reuse and restoration } \\
\text { Hazardous substances } \\
\text { Product consumers' demand } \\
\text { Product storage amount } \\
\text { Waste weight } \\
\text { Waste type } \\
\text { Waste location } \\
\text { Waste reused amount }\end{array}$ & $\begin{array}{ll}\text { - } & \text { Production process } \\
\text { energy and material } \\
\text { consumption, } \\
\text { - } & \text { Air emissions } \\
\text { - } & \text { Waste generation during } \\
\text { production processes } \\
\text { - } \text { Water consumption } \\
\text { - } & \text { Energy consumption }\end{array}$ & $\begin{array}{ll}\text { - } & \text { Logistics } \\
\text { - } & \text { Labour force } \\
\text { - } & \text { Waste collection centres } \\
& \text { (location) }\end{array}$ & $\begin{array}{ll}\text { - } & \text { Blockchain } \\
\text { - } & \text { Sensors } \\
\text { - } & \text { IoT } \\
\text { - } & \text { Big Data } \\
\text { - } & \text { Smart bins } \\
\text { - } & \text { Sorting robots } \\
\text { - } & \text { Recycling robots } \\
\text { - } & \text { Data analytics } \\
\text { - } & \text { Deep learning technique } \\
\text { - } & \text { Multivariate } \\
& \text { model equation } \\
\text { - } & \text { BIM } \\
\text { - } & \text { CAD/CAE 3D } \\
\text { - } & \text { Web technologies } \\
& \text { (to identify the } \\
& \text { localization of waste } \\
& \text { per category) }\end{array}$ \\
\hline
\end{tabular}




\subsubsection{Industrial Symbiosis}

To exchange valuable resources, Industrial Symbiosis might be adopted as CM strategy, as done by Nespresso that takes back the used capsules to exploit the remaining coffee as fertilizer to be given to rice fields [73]. To ensure that this partnership can be suitable for both sides, Nespresso has to create awareness in its consumers to stimulate the product turn back and it has to analyse the type of waste it has, to be aligned with the requests for the rise fields. Therefore, this strategy involves different stakeholders among which the waste producer, the waste user, the waste treatments companies and waste transportation companies [74]. Indeed, this strategy aims to make companies collaborate by exchanging by-products, resources, and scraps under the common goals of environmental and economic sustainability that might be enabled by collaborative platforms or existing web platforms to develop input-output matching tools [75]. Considering product and process categories, the necessary information refers to the types and quantities of resources consumed, the types and quantities of waste and by-products produced and the conversion processes, all backed by economic information concerning the exchange. This allows us to evaluate what resources can be recovered from waste or by-products, what waste or by-products can be used as raw material and last, what technologies and processes are necessary for the conversion [76]. In addition, information regarding availability and requirements of resources in terms of quantity, time and price should be gathered together with process factors like the temperature, the flow rate, the pressure, the enthalpy [75], the concentration of chemical species and their toxicity, the flow of energy, water used for the concrete usage of these resources [77]. All these issues influence the managerial decisions, for instance, it is important to evaluate the distance among the entities exchanging resources, and the profitability related to the exchanges [76].

To summarise, linking these findings with RQ1 and RQ2, manufacturers embracing this strategy are recommended to gather information either internally and externally to evaluate the possible matches with other actors. Therefore, they must collect data regarding type and quantity of waste and by-products produced internally. This information is necessary to be shared externally to allow the selling of these resources or to allow the exchange of the resources in case waste and by-products produced by others could be useful for their productive activities. For this strategy is important the investment in collaborative platforms to be able to share and obtain relevant data. Therefore, this also requires investing in data format standardisation and system integration to ensure an easier access to data for different actors.

The results are reported in Table 7.

Table 7. Industrial Symbiosis adoption data, information and technologies/tools.

\begin{tabular}{|c|c|c|c|}
\hline \multicolumn{4}{|c|}{$[19,74-78]$} \\
\hline Product & Process & Managerial & Technology/Tools \\
\hline $\begin{array}{l}\text { - } \begin{array}{l}\text { Type and quantity of } \\
\text { by-products and waste }\end{array} \\
\text { produced } \\
\text { - } \quad \text { Type (e.g., material, } \\
\text { energy, water) and } \\
\text { quantity of resources } \\
\text { consumed } \\
\text { - } \text { Timespan of availability } \\
\text { - } \\
\text { Resource nutrient } \\
\text { (e.g., the characterization } \\
\text { of the resource regarding } \\
\text { its reinstatement into } \\
\text { biological or } \\
\text { technical cycles) } \\
\text { - Toxicity of resources } \\
\text { - Cyclicity of resources }\end{array}$ & $\begin{array}{l}\text { - Conversion processes } \\
\text { (i.e., from waste and } \\
\text { by-product to resource) } \\
\text { information (e.g., skills, } \\
\text { material, energy, water) } \\
\text { - Monitoring of physical } \\
\text { system data during the } \\
\text { conversion, such as } \\
\text { temperature, flow rate, } \\
\text { pressure, enthalpy, } \\
\text { the concentration of } \\
\text { chemical species } \\
\text { of streams } \\
\text { - Emissions } \\
\text { - Costs }\end{array}$ & $\begin{array}{l}\text { - Location of the } \\
\text { entities collaborating } \\
\text { in the industrial } \\
\text { symbiosis } \\
\text { - Storage of } \\
\text { information } \\
\text { (e.g., name, address, } \\
\text { industry, etc.) of the } \\
\text { entities collaborating } \\
\text { in the industrial } \\
\text { symbiosis } \\
\text { - Profitability } \\
\text { estimation coming } \\
\text { from the exchange }\end{array}$ & $\begin{array}{l}\text { - Collaboration platforms } \\
\text { - Existing web platforms } \\
\text { (e.g., U. S. Materials Market } \\
\text { Place, WasteIsNotWaste, } \\
\text { Resource Efficient Scotland, } \\
\text { Minnesota Materials } \\
\text { Exchange, The Waste } \\
\text { Exchange) } \\
\text { - Ontology and Ontological } \\
\text { frameworks } \\
\text { - PLM systems } \\
\text { - } \text { - Waste exchange registry } \\
\text { - } \quad \text { Lifecycle inventory database }\end{array}$ \\
\hline
\end{tabular}




\subsubsection{Closed-Loop Supply Chain and Reverse Logistics}

A valid example of closed-loop supply chain or reverse logistics strategy adoption is the one of ARC, which creates partnerships with both manufacturers and distributors to ensure the maximisation of the returned products value while protecting the new products value [54].To allow that this can happen in an efficient way, ARC has to collect data regarding the type, the quantity, the time and the quality of returned products.

The reverse logistics is based on all the logistic activities required to transform used products into reusable products [79]. Being products classified according to the remaining useful life and their status, the information to be gathered on the product side are product condition [80], product lifecycle stage, product design, inventory of returned products, product perishability, product complexity and hazardous material composition [81]. Moreover, considering the uncertainties regarding the returned products, there should be the necessity to gather data regarding time, quality, quantity, and types of returned products, to then develop a plan and decide whether to recondition, reuse or sell the returned product in a secondary market [49]. Whenever a product is turned back, it is important to evaluate the reasons why it has been returned. It might be a defective product, or it needs maintenance or repair activities, or it has been returned due to excess of products [82] This information influence disassembly activities and remanufacturing activities required by the product [49].

Moreover, to establish an efficient reverse logistic network, other information concerning managerial and processes issues needs to be gathered to direct investments such as managerial commitment, internal reorganization, institutional issues management in terms of regulation and taxation, technological investments to establish processes supporting $\mathrm{CM}$ strategies and last, informational challenges, considering the difficulties encountered for information exchanges [83]. In reverse logistics, supplier management practices should be revised. Environmental auditing of suppliers must be performed (e.g., on injury reduction in terms of deforestation and material recycling, or on emission reduction or cost savings [84] that might be done also through a questionnaire, the introduction of a compliance statement, a product testing report, the bill of material (BOM) of products and components purchased and the establishment of environmental requirements for purchasing [85]. The hygiene and safety conditions of suppliers must be checked, as well as their partnerships with green organizations, their adherence to green policies, their pollution control initiatives, the appropriate staff training, the environmental standards adoption, the quality and time of the service provided, the economic data, and the usage of environmentally friendly technology and materials [86]. Customer management should be revised too since it is necessary to stimulate new demand for reconditioned products and a remarketing strategy can be put in place [87].

The gathering of these data might be eased by the adoption of RFID or IoT sensors and actuators that can be furtherly integrated through the usage of PLM, Relational Database Management Systems or Database Handling Systems [87]. ICT systems are considered essential elements to support reverse logistics and to store the right information [88]. Among them, ERP is considered one of the most important instruments to streamline information flows and to enable the returned products monitoring [79].

To summarise, bonding these findings with RQ1 and RQ2, manufacturers embracing this strategy are recommended to ensure the tracking of the product along its lifecycle to monitor both the conditions and localisation allowing its efficient and economically convenient recovery. A network must be designed appropriately thus, data regarding the actors involved are extremely relevant. With this intent, supportive technologies can be considered valuable investments, among which the integration of information and communication systems allowing the right setting of reverse logistics activities and tracking technologies such as RFID.

The results are reported in Table 8. 
Table 8. Closed-loop supply chain and Reverse Logistics adoption data, information and technologies/tools.

\begin{tabular}{|c|c|c|c|}
\hline \multicolumn{4}{|c|}{$[44,49,79-103]$} \\
\hline Product & Process & Managerial & Technology/Tools \\
\hline 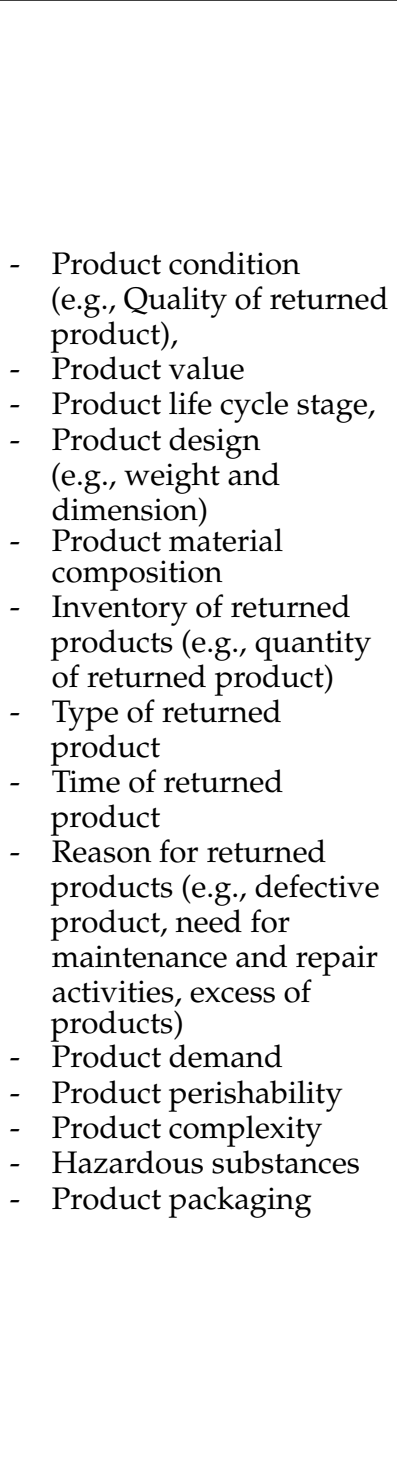 & 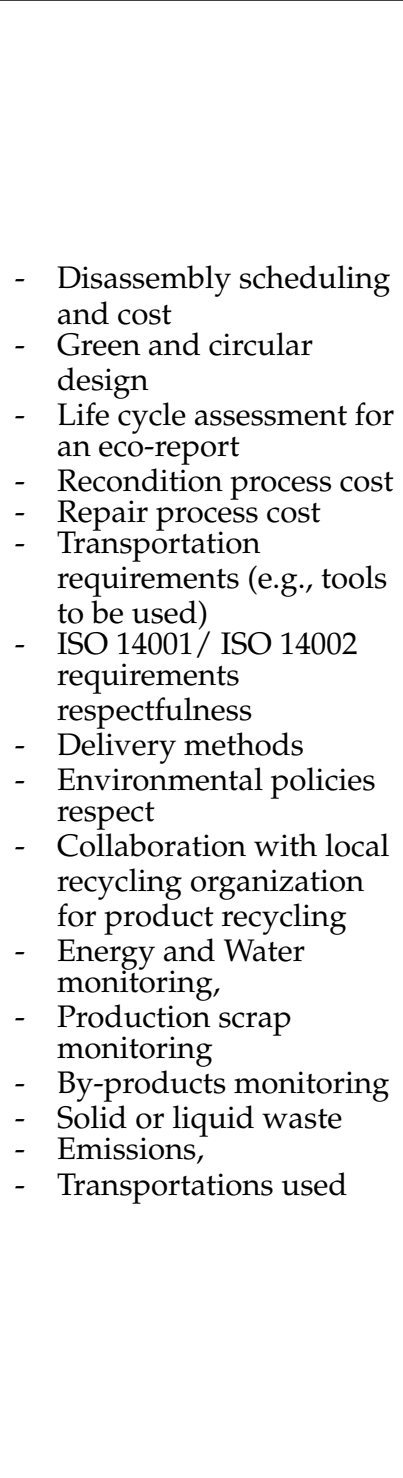 & 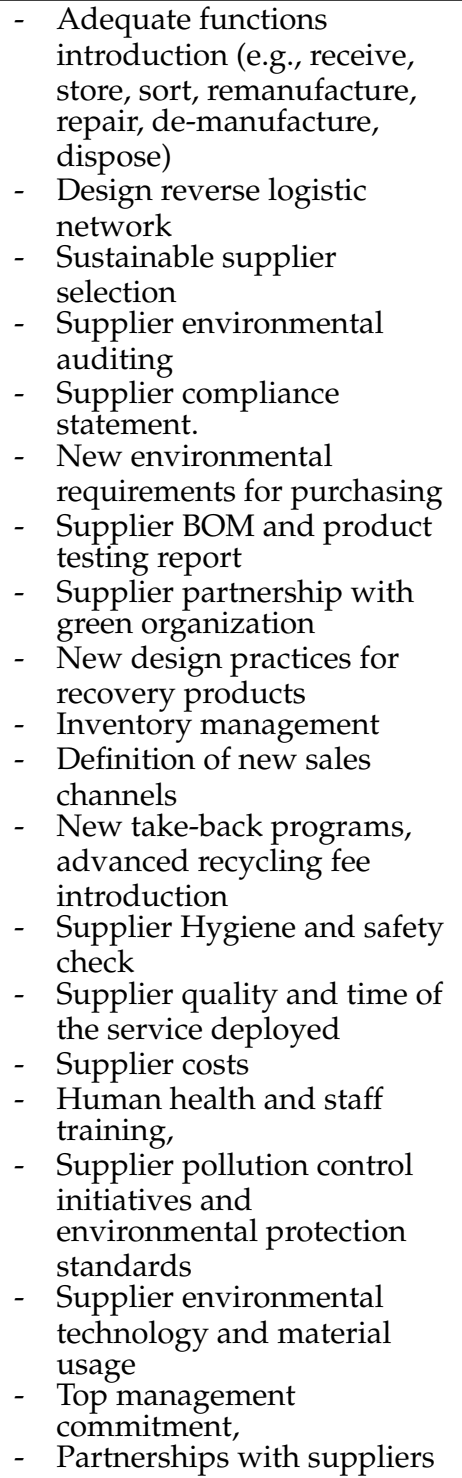 & $\begin{array}{ll}\text { - } & \text { ICT } \\
\text { - } & \text { Information systems } \\
\text { as ERP } \\
\text { - } & \text { Recovery BOM } \\
\text { - } & \text { Material } \\
& \text { Requirements } \\
& \text { Planning (MRP) } \\
\text { - } & \text { Recovery } \\
& \text { Requirements } \\
& \text { Planning } \\
\text { - } & \text { Sharing platforms } \\
\text { - } & \text { PLM, } \\
\text { - } & \text { Relational Database } \\
& \text { Management } \\
& \text { Systems } \\
\text { - } & \text { Database Handling } \\
\text { Systems } \\
\text { - } \quad \text { Green information } \\
\text { technologies systems } \\
\text { - Eco-database for } \\
\text { products }\end{array}$ \\
\hline
\end{tabular}

\subsubsection{Servitization}

Another CM strategy is the servitization and linked to that, the PSS is one of the most diffused business models in CM adoption. For instance, Philips Lighting is switching to PSS to control the entire product lifecycle [104]. Since Philips Lighting provides a service, data collection but be ensured along the product lifecycle to give the right support to consumers. These business models, on the process side, are monitored through data regarding carbon emissions, renewable energy consumption, climate change impact, waste production, resource depletion [50], production scheduling, work procedure for disassembly, energy and materials used from renewable resources, waste, and energy recovered by the system [105]. On the product side, information on the possibility to disassemble, remanufacture, recycle and reuse the product to provide the right service is required [50], as well as the product characteristics, the usage of biodegradable materials, and the level of product flexibility in terms of the number of users that potentially can use the product [105]. Last, another important aspect to be monitored regards the auxiliary services provided to the users, such as product maintenance, repair, parts replacement, 
recall, and scrap recycling. These services are required to be integrated with information throughout the product lifecycle [52] to update customer management practices. Indeed, a market analysis must be performed by monitoring customers demand, needs, requirements, and competitors' actions. Regarding the suppliers' management, data concerning the supplier innovation level of products, the transportation requirements and expertise on processes and technologies adopted need to be gathered [106].

One of the most diffused technologies supporting servitization is the Big Data Analytics technique leveraging on smart products [50]. Big Data Analytics can support companies in detecting hidden knowledge, to improve their competitive advantage, among which the relation between lifecycle decisions and process parameters [33].

Wrapping up, linking these findings with $\mathrm{RQ} 1$ and RQ2, manufacturers embracing this strategy are recommended to collect data regarding consumers' behaviours and product conditions, during the usage phase, to ensure the provision of tailored services. This allows the stable maintenance of product functionalities and it might support an improved design for the future. Therefore, big data analytics can be suitable to back smart products tracking and analysing data on both the service delivery and the usage phase.

The results are reported in Table 9.

Table 9. Servitization adoption data, information and technologies/tools.

\begin{tabular}{|c|c|c|c|}
\hline \multicolumn{4}{|c|}{$[33,50,52,105-110]$} \\
\hline Product & Process & Managerial & Technology/Tools \\
\hline 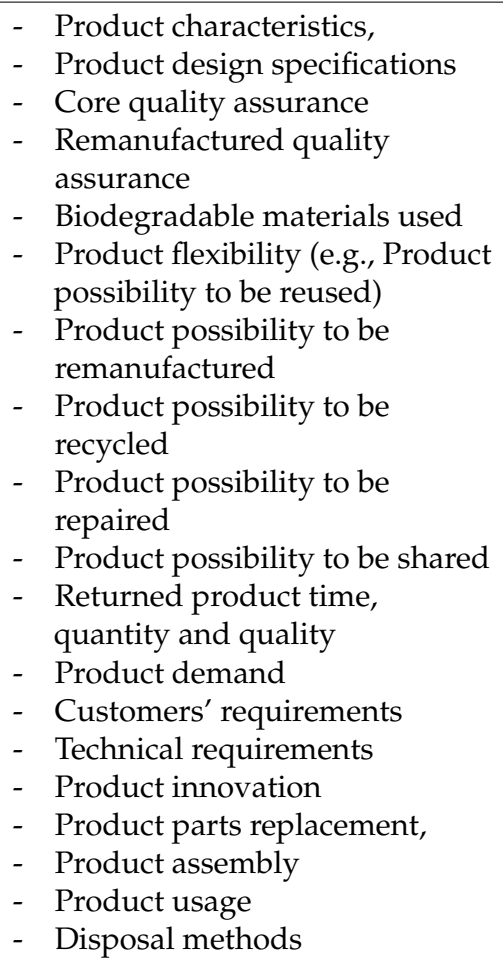 & $\begin{array}{ll}\text { - } & \text { Production scheduling } \\
\text { - } & \text { Manufacturing } \\
\text { specification } \\
\text { - } & \text { Disassembly work } \\
\text { procedure } \\
\text { - } \text { Material and scrap } \\
\text { recycling process } \\
\text { - } \quad \text { Energy and Material } \\
\text { used from renewable } \\
\text { resources } \\
\text { - } \text { Waste and energy } \\
\text { recovered by the } \\
\text { system } \\
\text { - Transportation } \\
\text { requirements } \\
\text { - Product operations } \\
\text { - Product maintenance } \\
\text { - Product repair }\end{array}$ & $\begin{array}{ll}\text { - } & \text { Insurance policies } \\
\text { - } & \text { Competitors analysis } \\
\text { - } & \text { Collection centres } \\
\text { - } & \text { Training the } \\
\text { employees to deploy } & \text { the service } \\
\text { - } & \text { Sharing service } \\
\text { - } & \text { Product recall } \\
& \text { management }\end{array}$ & $\begin{array}{ll}\text { - } & \text { Big data analytics } \\
\text { - } & \text { Smart products } \\
\text { - } & \text { IoT } \\
\text { - } & \text { Cyber Physical } \\
& \text { Systems } \\
\text { - } & \text { Data mining } \\
\text { - } & \text { Cloud } \\
& \text { Manufacturing } \\
\text { - } & \text { Artificial Intelligence } \\
\text { - } & \text { Intranet }\end{array}$ \\
\hline
\end{tabular}

\subsubsection{Resource Efficiency and Cleaner Production}

Resource efficiency (i.e., material and energy efficiency) and cleaner production are considered relevant $\mathrm{CM}$ strategies too. Both of these strategies are promoted for instance by Apple (2020) which on one side, regarding the resource efficiency, is forcing to design lighter products (and packaging) to ensure a reduced amount of material usage, on the other side, for cleaner production, establishes relationships only with suppliers using renewable energy sources and accepting their Zero Waste Program aiming to divert the $100 \%$ of waste from landfills [111]. Apple has to collect data regarding its suppliers, both on 
their activities and certifications, but it needs also to collect data regarding the product design to improve the product sustainable characteristics generation by generation.

Concerning the adoption of these strategies, during the manufacturing processes, energy usage should be monitored and this is affected by product type, machines used and state of the final product [112]. Technologies like photovoltaic panels to produce energy, sensorized glasses to adjust heat and light inside the building and water reuse technologies are used for the right implementation of these strategies [113].

To summarise, linking these findings with RQ1 and RQ2, manufacturers embracing these strategies are recommended to collect data regarding the sustainability of their productive activities or of those of the partners selected, such as of the suppliers. This allows us to keep under control the environmental impacts of the company and its network. For the adoption of these strategies, investments in advanced and eco-technologies are suggested on one side to monitor the assets conditions reducing the scrap generation, and on the other side to ensure high environmental standard of the activities.

The results are reported in Table 10.

Table 10. Resource Efficiency and Cleaner Production adoption data, information and technologies/tools.

\begin{tabular}{|c|c|c|c|}
\hline \multicolumn{4}{|c|}{$[112,113]$} \\
\hline Product & Process & Managerial & Technology/Tools \\
\hline $\begin{array}{l}\text { - } \begin{array}{l}\text { Product type and } \\
\text { characteristics }\end{array} \\
\text { - } \begin{array}{l}\text { Final status of the } \\
\text { product }\end{array}\end{array}$ & 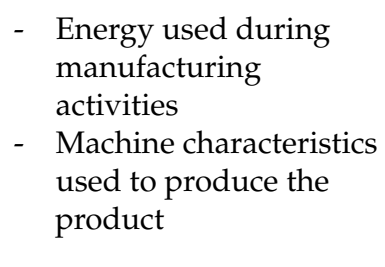 & - & 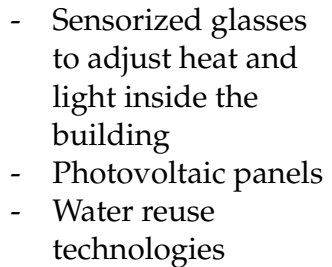 \\
\hline
\end{tabular}

Regardless of the strategy adopted, the top management commitment is important to drive the modification of internal managerial factors, to respect the adoption of new regulations, and to introduce new customers and suppliers' management strategies to embrace CM. All these factors required to be supported also by government financial resources and new technological investments [103].

\section{Discussion}

The transition towards CM involves the entire organization and implies an orchestration with the whole ecosystem [114]. Manufacturers, through the gathering of the right data and information, are facilitated in managing more effectively the circular requirements that might arise along the product lifecycle [115]. On one side, this SLR showed a high correlation among the data and information necessary to adopt each strategy, strengthening the possibility to exploit the same data for the concurrent adoption of different $\mathrm{CM}$ strategies in embracing $\mathrm{CM}$. For instance, data regarding product characteristics and composition are the basement for each strategy to be adopted, and the information for the scheduling of the activities, with various purposes, is fundamental for the optimization of the efforts required to extend resources lifecycle. More precisely, to highlight these concepts, data regarding product composition can be extremely useful and common to be gathered if looking at circular design strategy. At the same time this data is extremely important for the correct adoption of all the other strategies, like recycling and remanufacturing for example, since without this information the resources are more difficult to be treated. In addition, a common ground for all the strategies is the necessary engagement with external actors and thus, the importance to introduce integrated platforms allowing the streamlining of the information sharing among different entities is underlined. This is true in general, no matter the scale of the manufacturer considered since the common required data can 
be available in case of a correct data gathering and sharing. On the other side, it emerged that each strategy is characterised by four main categories, highly integrated among them, out of which three correspond to the categories of data and information (i.e., product, process, management) to be gathered and managed by the manufacturer in charge of the transition, while the fourth category corresponds to the technologies and tools to gather and manage data and information to create exploitable knowledge.

The analysis of these categories enabled to define a theoretical framework (see Figure 6) which provides an overview of the relevant areas to be monitored in CM by a manufacturing company. Other frameworks already exist in the literature, such as the "Butterfly" framework developed by The Ellen MacArthur Foundation (2015) to investigate the possible restorative paths of materials and energy flows [6], and the one developed by OECD (2018) to investigate circular business models enhancing CE values [116]. The framework proposed in this contribution, evidently characterized by great commonalities with the previous ones, aims to revisit them from the perspective of data and information valorisation. Therefore, both the frameworks just mentioned, i.e., the "Butterfly framework" and the "OECD framework", are not specific for the manufacturing sector and they mainly depict the different solutions and strategies to be adoptable in CE by describing the possible outcomes in a qualitative manner. They both do not provide a structured analysis regarding the requirements for the distinctive solutions. Actually, the present framework is sector specific, being focused only on the manufacturing sector. It has been built to allow manufacturers to have a wide and complete spectrum of the information needed to adopt $\mathrm{CM}$. Indeed, it provides in detail both the data and the technologies required to address each CM strategy. Moreover, this structured analysis allows manufactures to evaluate the synergic potentials among the different strategies and to take more informed decisions on the different adoptable CM strategies."

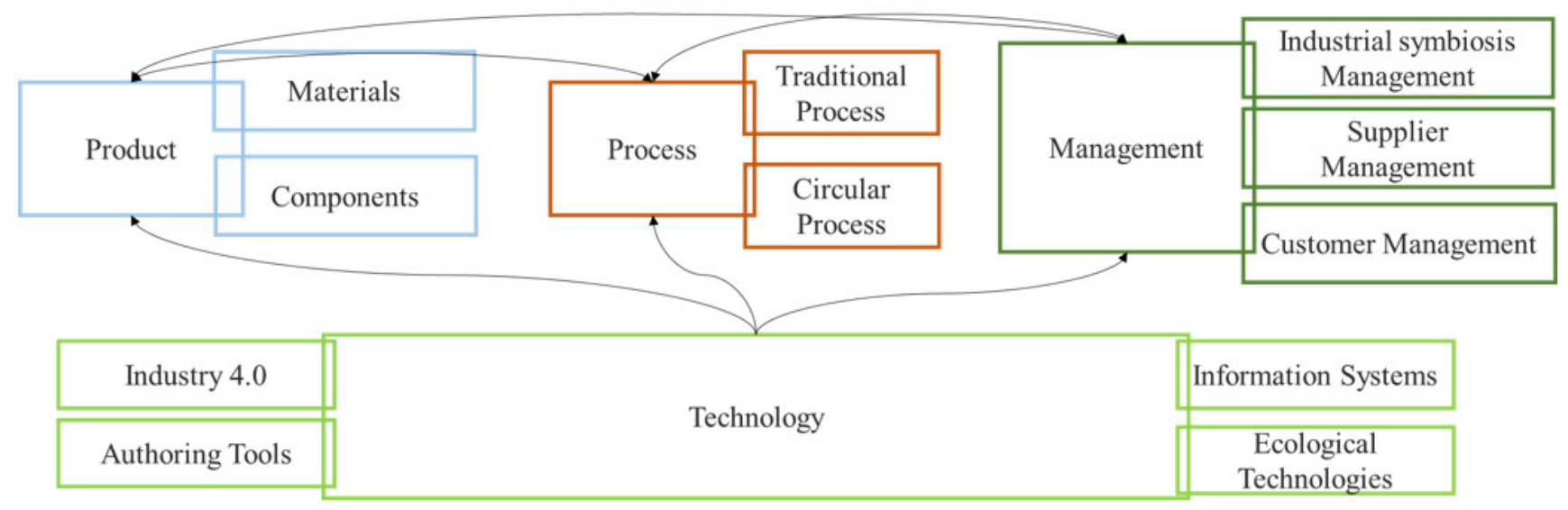

Figure 6. Theoretical framework.

The framework categories are discussed in the sub-sections below.

\subsection{Product Category}

The "product" category is the gear boosting the entire ecosystem towards CM and the findings of this review revealed the need to gather data and information regarding the physical composition of products, in terms of both components and materials (see the light blue block in Figure 6). The importance of this category has been also highlighted by the data detected for it which are required mainly by all the different $\mathrm{CM}$ strategies.

This category gains importance especially dealing with the circular design, representing the origin of the product lifecycle. Thus, considering that the main goal of designing "circular" products is to enable the extension of their lifecycle [39], and the reduction of resources used [11], some data such as assembly instruction, product modularity, features, and geometry are revealed to be important to understand the structure of the components. 
This would be linked to the gathering of data necessary to evaluate the possibility to disassemble and repair the product and to ensure to address both technical requirements and customers' needs. An important piece of data, common to all the CM strategies, is the customers' demand-type since it enables us to understand if the company is able to both address the market needs and stimulate a demand aligned with the company circular values. Besides, the review showed the importance to assess material toxicity, material mix, and material weight to limit the negative social and environmental impacts. Data regarding material composition are important also for reverse logistics strategy to select the right material type, for industrial symbiosis strategy to appropriately exchange waste, and for waste management and recycling to properly manage the material to be wasted and recycled. To close the resources loops, information like product final status, product usage, product remaining useful life and product value, gain importance at product EoL. These data are common for remanufacturing, reuse, recycle, servitization and reverse logistics strategies. Peculiar information is required while dealing with reverse logistics like the product perishability and the time and quantity of turn-back products.

As final remark regarding future trends, the gathering of data and information on products will be facilitated more and more thanks to the introduction of sensors into products design characteristics. Thus, smart products development will encourage more circular behaviors and will ensure the real time collection of data along the product lifecycle enabling to facilitate the resources lifecycle. Therefore, product characteristics and conditions will be easily used in this scenario, and consumers will be supported in managing products in a more responsible manner. Moreover, the static perspective will be still representative for the product category and thus, the BOM and the recovery BOM will cover a promising role in ensuring the embracement of $\mathrm{CM}$ by manufacturers since they allow to have under control information regarding product characteristics starting from their initial design and material requests.

\subsection{Process Category}

The "product" category is strictly related to the "process" one (see the brown block in Figure 6) since, to enable the concurrent adoption of different $\mathrm{CM}$ strategies, it is not enough to act on the product, by adapting and changing it through a suitable design. New processes necessitate to be introduced in the company (i.e., circular processes) and, traditional processes are required to be modified, which is possible through the appropriate data and information gathering.

Circular processes usually take their names from the related strategy, and represent the core for the adoption of CM strategies like remanufacture, reuse, recycle, disassembly, servitization, industrial symbiosis, and reverse logistics, since they concretely make regenerate resources.

Some data are distinctive for a certain strategy. For instance, data characterising disassembly refer to the estimation of the number of operations to reach a target component and the time spent in doing it. Industrial symbiosis requires the evaluation of the necessary resources to convert the waste into a resource (e.g., skills required, amount and type of necessary material, the amount of energy and water) and to monitor the physical system during the conversion process by gathering data like pressure, temperature, and emissions. The distinctive data characterising the reverse logistics are those regarding the transportation methods and requirements (e.g., ad hoc tools necessary to transport different types of products).

Other data and information belonging to the process category are instead common to all, or to the majority, of the CM strategies. Actually, economic data to ensure economic sustainability are relevant for several strategies, among which reuse, remanufacturing, reverse logistics, and servitization that require to monitor transportation, collection, supply and reconditioning costs. Several strategies share also environmental-related data such as the evaluation of the amount and the typology of resources used, and the emissions generated in each process. Moreover, social-oriented data allowing to satisfy the entire 
demand, like the flexibility of internal processes, the scheduling of production plan and the scheduling of disassembling and remanufacturing activities, are common to different strategies. Concerning social aspects, data and information regarding workers' daily activities are gathered for all the strategies to monitor workers' ergonomic and safety conditions that sustain improvement of company efficiency by narrowing resources usage. All these shared data are required to be gathered also for the traditional manufacturing processes such as design, production, and logistics. Indeed, both new circular processes and updated traditional manufacturing processes necessitate to be implemented in a concurrent and coordinated way whenever $\mathrm{CM}$ strategies are adopted, requiring to enlarge the spectrum of data to be gathered.

All these processes influence one another. For instance, circular processes can be efficiently adopted only if it is delivered an appropriate service of maintenance and repair, and if it is possible the "turn back" of products. Therefore, the circular processes must be backed by the introduction of an adequate reverse logistic network [49] influencing the traditional logistics processes.

As final remark regarding the future trends on process category, manufacturers will need to ensure an appropriate internal organization encountering the needs from the traditional and circular processes. Therefore, the collection of data regarding these processes allows us to balance the resources needed and satisfy consumers demand. Data and information gathering and usage will allow the right scheduling of the activities to concurrently address different goals. This will be facilitated by the introduction of advanced technologies and information systems enabling both the internal alignment and the sharing of information with external actors whenever required.

\subsection{Management Category}

To ensure the orchestration of the entire ecosystem, also the management is influenced (see the dark green block in Figure 6). Managerial procedures might require to be modified and new ones need to be introduced, especially while dealing with industrial symbiosis and reverse logistics. They both require the involvement of stakeholders both internal and external to the supply chain, all needing to be appropriately managed. This review enlightens the relevance of data and information concerning three main aspects:

1. Supplier management: suppliers selection criteria need to be adjusted to produce products with the appropriate materials, such as non-toxic, biodegradable, and recyclable materials [84]. For instance, a new auditing procedure including ad hoc questionnaires could be introduced to gather data assessing supplier sustainability and circularity. In addition, to boost the competitiveness of the company and ensure product circularity, it is necessary to strengthen the relationships with the selected suppliers on the long-term, inevitably requiring data transparency;

2. Customer management: circular products production is justified only if there is an acceptable demand from customers which requires stimulation through marketing actions [60], among which are take-back programs, which allow customers to bring back, instead of discard, those products no more valuable for them. Therefore, customer management has to be updated to understand how to address customers' needs by taking advantage of an increasing "green market". Besides, it would help in training customers' behaviours towards the acceptance of circular products (e.g., recycled products);

3. Industrial symbiosis management: to retain value from the scrap, generated due to internal production inefficiencies, this can be either analysed to be reused or it can be exchanged with other external industrial companies. This second option requires an ad hoc management of these third parties to establish partnerships whenever possible.

As final remark regarding the future trends on management category, new solutions to establish trusted relationships will be developed. Therefore, partnerships with external stakeholders represent the right means embracing $\mathrm{CM}$ to fully exploit the benefits originated from this paradigm. To make this happen, data sharing is extremely important and 
thus, platforms or integrated systems implementation will be encouraged in the future. Moreover, the three types of stakeholders above mentioned (i.e., consumers, suppliers and partners in an industrial symbiosis network) cover the most relevant actors to engage with allowing the manufacturer to cover the entire product lifecycle having the necessary data to embrace CM.

\subsection{Technology}

Last, technology becomes the backbone of the $\mathrm{CM}$ transition through data valorisation (see the light green block in Figure 6). Both advanced I4.0 technologies, as recycling robots supporting recycle strategy [62], and information systems, like ERP supporting closedloop supply chain [79], start covering relevant positions in CM. Moreover, information systems can be fed through different sources of data among which the authoring tools. Considering the rising need to appropriately manage products from their BoL, authoring tools emerged to be another important tool allowing to have lots of information regarding product characteristics, especially relevant for the circular design strategy [37]. In addition, ecological technologies emerged to be useful in supporting cleaner production and resource efficiency adoption embracing CE principles, such as the use of renewable sources of energy. For instance, photovoltaic panels and sensorized glasses are considered suitable for appropriate energy management [113]. in CM:

To summarise, below are reported the four main classes of supportive technologies

1. Industry 4.0 technologies, such as Big Data analytics and robots;

2. Information Systems such as ERP, MRP, and PLM;

3. Authoring Tools such as CAD/CAEX and CAD 3D;

4. Ecological Technologies such as photovoltaic panels and sensorized glasses.

As final remark regarding the future trends of the technology category, the introduction of the four types of technologies just mentioned need to be considered in the strategic plans of manufacturers. Therefore, ecological technologies investments need to be specific according to the CM strategy willing to be adopted, and investments in ICT for instance will be required regardless the strategy adopted. This is especially true if looking at the CM strategies concurrent adoption, which requires the synergic implementation and integration of these technologies to allow a more comprehensive data gathering and usage.

\section{Conclusions}

This research operated an SLR intending to identify and classify all the relevant information, data, and supportive technologies and tools, required to aid manufacturers to approach to $\mathrm{CM}$ and manage the $\mathrm{CM}$ strategies. In detail, this research provides an overview of relevant areas to be monitored by manufacturers in $\mathrm{CM}$, adopting different but correlated strategies, in an efficient and structured way. The review has been operated for each CM strategy identified in [13], analysed through four main categories.

From a scientific perspective, this research enables us to cover the identified gap facilitating data and information exploitation as necessary resources to adopt CM.

The first result of this SLR is the detection of the specific data and information needed by manufacturers in CM, classified per each strategy and category. From this review, it emerged that some data and information are peculiar for specific strategies (e.g., product maintenance in servitization), while others are common to different strategies (e.g., product characteristics) which might help and sustain their concurrent adoption. Therefore, the need to gather similar, or in some cases exactly the same data and information, strengthen the necessity to concurrently adopt $\mathrm{CM}$ strategies to embrace $\mathrm{CM}$. Moreover, the data gathering and usage can be facilitated by the introduction of specific technologies which might be used in a synergic manner to support the concurrent adoption of the different strategies too. These findings allowed to address both of the RQs. In addition, relying on these findings, specific recommendation for manufacturers, regarding the 
most relevant data to be gathered and technologies to invest in, have been provided for each single CM strategy.

The second finding of this SLR is that manufacturers, for the appropriate embracement of the different CM strategies, necessitate to monitor and manage data and information concerning the "product", the "processes" and the "management", relying on the adoption of supporting "technologies/tools" to gather and use them. From this, the development of the theoretical framework (depicted in Figure 6). More in detail, for each of the four categories are elucidated the possible future trends which can be useful both for scholars, to undertake new studies in those directions, and for manufacturers to evaluate adequate future investments.

In line with that, the third result is reflected in the development of the theoretical framework (see Figure 6), embodying the review results. This gives a paramount perspective of classes of data required in CM and supporting technologies to gather and use data. It raises manufacturers' awareness regarding the type of internal and external data that should be gathered from internal activities, and from external stakeholders like consumers and suppliers to embrace CM strategies.

From a managerial perspective, this review provides an overview of the different information and data that manufacturers have to gather to adopt each CM strategy. This analysis allows us to create awareness in manufacturers regarding the need to exploit data gathered not only internally but also externally, by underlining the importance to share data in CM adoption. This requires us to promote data standardisation in terms of format too, in order to facilitate the exchange of data. Therefore, data exchange would favour the collaboration and the exchange of knowledge which benefits the exchange of all the other resources flows (e.g., materials). Actually, the theoretical framework developed elucidates the macro categories in which data should be gathered to be used for circular purposes, supporting manufacturers to clarify the areas to be monitored in CM. Therefore, this work represents the basement to allow a structured support for the decision-making process of manufacturers in embracing CM strategies. In addition, relying on this research, manufacturers can be stimulated in using specific technologies to gather and use data according to the CM strategy adopted. On one side, this can sustain tailored technological investments for the exploitation of data relying on the integration of different systems (such as the MES with the PLM and ERP). On the other side, the digitization path undertaken recently by manufacturing companies can be seen through new lenses. Thus, new usage of the technologies, sometimes already considered for investment to optimise companies' daily activities such as Industry 4.0 technologies, can be operated to enhance sustainable performances by supporting the concurrent adoption of CM strategies relying on the appropriate data and information.

From the policymakers' perspective, this review puts the basis to define adequate countermeasures and actions to promote the sharing of information management among industrial actors and with final consumers, to boost the sustainability of the manufacturing sector through the adoption of CM. Policymakers can take advantage for their future plans re-directing investments towards specific technologies that emerged to be the most promising to exploit data value under a CM perspective.

One of the main limitations of the present analysis is that the framework proposed is based only on the scientific literature and calls for further research to give practical and empirical evidence to the results obtained. In addition, all these findings opened the possibility for future studies:

- A conceptual data model structured on the data and information detected in this review needs to be developed to operationalise what has been so far theoretically obtained to bridge the managerial and operational levels of manufacturing companies throughout the transition towards CM. This model should enable to demonstrate how the concurrent adoption of different CM strategies can be eased through the exploitation of their data, information and technologies commonalities and it should be empirically verified; 
- A quantitative model could be developed to assess the impact that each data and information might have to pursue not only the specific CM strategy to which it is related but also the other strategies not theoretically supposed to be bonded. This would validate the links detected among the different $\mathrm{CM}$ strategies and also unveil new connections among them through practical evidence;

- The tracking and management of data and information could represent the basement to quantify the benefits derived from the usage of CM [117] and to measure the circular performances of manufacturers [118]. In the long run, this would create the foundation for the development of a model assessing the circular maturity level of manufacturing companies through the definition, calculation, and monitoring of specific key performance indicators;

- A deeper investigation of the identified data and information should be performed to better define their own characteristics (e.g., accessibility, timeliness). Among them, particular attention could be dedicated to data's level of granularity;

- Since the usage of the different type of data and information are linked to the actors in charge of gathering them, future studies should be dedicated to investigate who is responsible for their gathering and management. The unit of analysis should be shifted from the manufacturing company as a whole to its single functions, also including the need to engage connections not only among internal managers and employees but also with external stakeholders belonging to other entities;

- Both managerial and technological barriers faced by manufacturers in exploiting data in CM might be further investigated also from an empirical point of view;

- Last, extensive studies should be performed to uniquely define and propose to manufacturers the new procedures necessary to gather most of the data and information emerged to be relevant in CM.

Author Contributions: Conceptualization, F.A.; methodology, F.A.; validation, C.S.; formal analysis, F.A.; investigation, F.A.; writing-original draft preparation, F.A.; writing-review and editing, C.S. and M.T.; visualization, C.S.; supervision, C.S., S.T. and M.T. All authors have read and agreed to the published version of the manuscript.

Funding: This research received no external funding.

Informed Consent Statement: Not applicable.

Conflicts of Interest: The authors declare no conflict of interest.

\section{Acronyms}

BOM Bill Of Material

BoL Begging of Life

CE Circular Economy

$\mathrm{CM}$ Circular Manufacturing

EoL End of Life

ERP Enterprise Resource Planning

ICT Information and Communication Technology

KM Knowledge Management

\author{
MES Manufacturing Execution System \\ MoL Middle of Life \\ PLM Product Lifecycle Management System \\ PSS Product-Service System \\ SLR Systematic Literature Review \\ TBL Triple Bottom Line \\ WEEE Waste Electrical and Electronic Equipment \\ WIP Work in Progress
}

\section{References}

1. Boulding, K.E. The economics of the coming spaceship earth. In Environmental Quality in a Growing Economy: Essays from the Sixth RFF Forum; Resources for the Future/Johns Hopkins University Press: Baltimore, MD, USA, 2013; Volume 3, pp. 1-20, ISBN 9781315064147.

2. Caradonna, J. Sustainability: A history; Oxford University Press: New York, NY, USA, 2014.

3. WCED. Report of the World Commission on Environment and Development: Our Common Future; Oxford University Press: Oxford, UK, 1987.

4. Elkington, J. The Triple Bottom Line: Does It All Add up? Assessing the Sustainability of Business and CSR; Richardson, J., Henriques, A., Eds.; Taylor and Francis: Abingdon, UK, 2013; ISBN 9781849773348.

5. Garetti, M.; Taisch, M. Sustainable manufacturing: Trends and research challenges. Prod. Plan. Control 2012, 23, 83-104. [CrossRef] 
6. The Ellen MacArthur Foundation. Towards a Circular Economy: Business Rationale for an Accelerated Transition. 2015. Available online: https:/ / www.ellenmacarthurfoundation.org/assets/downloads/publications/TCE_Ellen-MacArthur-Foundation_26 -Nov-2015.pdf (accessed on 10 November 2019).

7. European Commission. Circular Economy Action Plan. 2020. Available online: https://ec.europa.eu/environment/circulareconomy/pdf/new_circular_economy_action_plan.pdf (accessed on 11 October 2020).

8. Zhu, Q.; Geng, Y.; Lai, K. Circular economy practices among Chinese manufacturers varying in environmental-oriented supply chain cooperation and the performance implications. J. Environ. Manag. 2010, 91, 1324-1331. [CrossRef]

9. Pagotto, M.; Halog, A. Towards a Circular Economy in Australian Agri-food Industry: An Application of Input-Output Oriented Approaches for Analyzing Resource Efficiency and Competitiveness Potential. J. Ind. Ecol. 2016, 20, 1176-1186. [CrossRef]

10. Ranta, V.; Aarikka-Stenroos, L.; Ritala, P.; Mäkinen, S.J. Exploring institutional drivers and barriers of the circular economy: A cross-regional comparison of China, the US, and Europe. Resour. Conserv. Recycl. 2018, 135, 70-82. [CrossRef]

11. Bocken, N.; de Pauw, I.; Bakker, C.A.; van der Grinten, B. Product design and business model strategies for a circular economy. J. Ind. Prod. Eng. 2016, 33, 308-320. [CrossRef]

12. Valkokari, P.; Tura, N.; Ståhle, M.; Hanski, J.; Ahola, T. Advancing Circular Business; Tampere University: Tampere, Finland, 2019; ISBN 9789521543074.

13. Acerbi, F.; Taisch, M. A literature review on circular economy adoption in the manufacturing sector. J. Clean. Prod. 2020, 123086. [CrossRef]

14. United Nations. Sustainable Development Goals. 2015. Available online: https:// sustainabledevelopment.un.org/?menu=1300 (accessed on 16 September 2020).

15. Schot, J.; Steinmueller, W.E. Three frames for innovation policy: R\&D, systems of innovation and transformative change. Res. Policy 2018, 47, 1554-1567. [CrossRef]

16. Kivimaa, P.; Boon, W.; Hyysalo, S.; Klerkx, L. Towards a typology of intermediaries in sustainability transitions: A systematic review and a research agenda. Res. Policy 2019, 48, 1062-1075. [CrossRef]

17. Tura, N.; Hanski, J.; Ahola, T.; Ståhle, M.; Piiparinen, S.; Valkokari, P. Unlocking circular business: A framework of barriers and drivers. J. Clean. Prod. 2019, 212, 90-98. [CrossRef]

18. Ritzén, S.; Sandström, G.Ö. Barriers to the Circular Economy-Integration of Perspectives and Domains. Procedia CIRP 2017, 64, 7-12. [CrossRef]

19. Halstenberg, F.A.; Lindow, K.; Stark, R. Utilization of Product Lifecycle Data from PLM Systems in Platforms for Industrial Symbiosis. Procedia Manuf. 2017, 8, 369-376. [CrossRef]

20. Grieves, M.W. Product lifecycle management: The new paradigm for enterprises. Int. J. Prod. Dev. 2005, 2, 71-84. [CrossRef]

21. Marconi, M.; Germani, M. An end of life oriented framework to support the transition toward circualr economy. In Proceedings of the 21st International Conference on Engineering Design, ICED17, Vancouver, BC, Canada, 21-25 August 2017 ; Volume 5.

22. Schmidt, N.; Lueder, A. The Flow and Reuse of Data: Capabilities of AutomationML in the Production System Life Cycle. IEEE Ind. Electron. Mag. 2018, 12, 59-63. [CrossRef]

23. Acerbi, F.; Taisch, M. Towards a data classification model for circular product life cycle management. In Product Lifecycle Management Enabling Smart X, Proceedings of the 17th IFIP WG 5.1 International Conference, PLM 2020, Rapperswil, Switzerland, 5-8 July 2020; Nyffenegger, F., Ríos, J., Rivest, L., Bouras, A., Eds.; Springer: Cham, Switzerland, 2020; pp. 473-486.

24. Sassanelli, C.; Rossi, M.; Pezzotta, G.; Pacheco, D.A.; Terzi, S. Defining Lean Product Service Systems (PSS) features and research trends through a systematic literature review. Int. J. Prod. Lifecycle Manag. 2019. [CrossRef]

25. Olivier, S.; Pires, S.P.; Loures, E.R.F.; Santos, E.A.P.; Cestari, J.M.P.A. Knowledge management for sustainable performance in industrial maintenance. In Proceedings of the IIE Annual Conference and Expo 2015, Nashville, TN, USA, 30 May-2 June 2015.

26. Xin, Y.; Ojanen, V.; Huiskonen, J. Knowledge Management in Product-Service Systems-A Product Lifecycle Perspective. In Proceedings of the 10th CIRP Conference on Industrial Product-Service Systems, IPS2 2018, Linköping, Sweden, 29-31 May 2018; Volume 73, pp. 203-209.

27. Alcayaga, A.; Wiener, M.; Hansen, E.G. Towards a framework of smart-circular systems: An integrative literature review. J. Clean. Prod. 2019, 221, 622-634. [CrossRef]

28. Farooque, M.; Zhang, A.; Thürer, M.; Qu, T.; Huisingh, D. Circular supply chain management: A definition and structured literature review. J. Clean. Prod. 2019, 228, 882-900. [CrossRef]

29. Tranfield, D.; Denyer, D.; Smart, P. Towards a Methodology for Developing Evidence-Informed Management Knowledge by Means of Systematic Review. Br. J. Manag. 2003, 14, 207-222. [CrossRef]

30. Kirchherr, J.; Reike, D.; Hekkert, M. Conceptualizing the circular economy: An analysis of 114 definitions. Resour. Conserv. Recycl. 2017, 127, 221-232. [CrossRef]

31. Merli, R.; Preziosi, M.; Acampora, A. How do scholars approach the circular economy? A systematic literature review. J. Clean. Prod. 2018, 178, 703-722. [CrossRef]

32. Sitcharangsie, S.; Ijomah, W.; Wong, T.C. Decision makings in key remanufacturing activities to optimise remanufacturing outcomes: A review. J. Clean. Prod. 2019, 232, 1465-1481. [CrossRef]

33. Ren, S.; Zhang, Y.; Liu, Y.; Sakao, T.; Huisingh, D.; Almeida, C.M.V.B. A comprehensive review of big data analytics throughout product lifecycle to support sustainable smart manufacturing: A framework, challenges and future research directions. J. Clean. Prod. 2019, 210, 1343-1365. [CrossRef] 
34. Maeda, J. The Laws of Simplicity. Design, Technology, Business, Life; MIT Press: Cambridge, MA, USA, 2006.

35. Sassanelli, C.; Urbinati, A.; Rosa, P.; Chiaroni, D.; Terzi, S. Addressing Circular Economy through Design for X approaches: A Systematic Literature Review. Comput. Ind. 2020, 120, 1-23. [CrossRef]

36. Fairphone. Fairphone as an Example of 'Circular Design'. 2019. Available online: https://forum.fairphone.com/t/fairphone-asan-example-of-circular-design/50303 (accessed on 16 September 2020).

37. Laurenti, R.; Sinha, R.; Singh, J.; Frostell, B. Some pervasive challenges to sustainability by design of electronic products-A conceptual discussion. J. Clean. Prod. 2015, 108, 281-288. [CrossRef]

38. Khetriwal, D.S.; First, I. Enabling Closed Resource Loops in Electronics: Understanding Consumer Disposal Behaviour using insights from Diffusion models. Econ. Res. Istraz. 2012, 25, 47-68. [CrossRef]

39. Wang, L.; Shen, B. A product line analysis for eco-designed fashion products: Evidence from an outdoor sportswear brand. Sustainability 2017, 9, 1136. [CrossRef]

40. Yang, Y.; Chen, L.; Jia, F.; Xu, Z. Complementarity of circular economy practices: An empirical analysis of Chinese manufacturers. Int. J. Prod. Res. 2019. [CrossRef]

41. Ramanujan, D.; Chandrasegaran, S.K.; Ramani, K. Visual Analytics Tools for Sustainable Lifecycle Design: Current Status, Challenges, and Future Opportunities. J. Mech. Des. Trans. ASME 2017, 139. [CrossRef] [PubMed]

42. Kumar, S.; Luthra, S.; Haleem, A. Customer involvement in greening the supply chain: An interpretive structural modeling methodology. J. Ind. Eng. Int. 2013. [CrossRef]

43. Wilson, G.T.; Smalley, G.; Suckling, J.R.; Lilley, D.; Lee, J.; Mawle, R. The hibernating mobile phone: Dead storage as a barrier to efficient electronic waste recovery. Waste Manag. 2017, 60, 521-533. [CrossRef]

44. Wong, C.W.Y.; Lai, K.H.; Cheng, T.C.E.; Lun, Y.H.V. The roles of stakeholder support and procedure-oriented management on asset recovery. Int. J. Prod. Econ. 2012, 135, 584-594. [CrossRef]

45. Jasiulewicz-Kaczmarek, M. Identification of maintenance factors influencing the development of sustainable production processes-A pilot study. IOP Conf. Ser. Mater. Sci. Eng. 2018, 400, 062014. [CrossRef]

46. Nagiligari, B.K.; Shah, J.; Sha, Z.; Thirugnanam, S.; Jain, A.; Panchal, J. Integrated Part Classification for Product Cost and Complexity Reduction. In Proceedings of the ASME 2014 International Design Engineering Technical Conferences and Computers and Information in Engineering Conference, Buffalo, NY, USA, 17-20 August 2014.

47. Zhang, Z.; Liu, G.; Jiang, Z.; Chen, Y. A cloud-based framework for lean maintenance, repair, and overhaul of complex equipment. J. Manuf. Sci. Eng. Trans. ASME 2015, 137. [CrossRef]

48. Baran, J. Designing a Circular Product in the Light of the Semantic Design Areas. In proceeding of 29th International Business Information Management Association Conference, Vienna, Austria, 3-4 May 2017.

49. Shaharudin, M.R.; Govindan, K.; Zailani, S.; Tan, K.C.; Iranmanesh, M. Product return management: Linking product returns, closed-loop supply chain activities and the effectiveness of the reverse supply chains. J. Clean. Prod. 2017, 149, 1144-1156. [CrossRef]

50. Doni, F.; Corvino, A.; Bianchi Martini, S. Servitization and sustainability actions. Evidence from European manufacturing companies. J. Environ. Manag. 2019, 234, 367-378. [CrossRef] [PubMed]

51. Relight. 2020. Available online: https://www.relightitalia.it/en/company (accessed on 16 September 2020).

52. Cavalcante, J.; Gzara, L. Product-Service Systems lifecycle models: Literature review and new proposition. Procedia CIRP 2018. [CrossRef]

53. Zhou, F.; Wang, X.; Lim, M.K.; He, Y.; Li, L. Sustainable recycling partner selection using fuzzy DEMATEL-AEW-FVIKOR: A case study in small-and-medium enterprises (SMEs). J. Clean. Prod. 2018. [CrossRef]

54. America's Remanufacturing Company (ARC). 2020. Available online: http://www.remancouncil.org/companies/americasremanufacturing-company (accessed on 16 September 2020).

55. Tan, Q.; Zeng, X.; Ijomah, W.L.; Zheng, L.; Li, J. Status of end-of-life electronic product remanufacturing in China. J. Ind. Ecol. 2014. [CrossRef]

56. Sakao, T.; Sundin, E. How to Improve Remanufacturing? A Systematic Analysis of Practices and Theories. J. Manuf. Sci. Eng. Trans. ASME 2019, 141. [CrossRef]

57. Goodall, P.; Sharpe, R.; West, A. A data-driven simulation to support remanufacturing operations. Comput. Ind. 2019, 105, 48-60. [CrossRef]

58. Tolio, T.; Bernard, A.; Colledani, M.; Kara, S.; Seliger, G.; Duflou, J.; Battaia, O.; Takata, S. Design, management and control of demanufacturing and remanufacturing systems. CIRP Ann. Manuf. Technol. 2017, 66, 585-609. [CrossRef]

59. Lush. Reduce, Reuse, Recycle Lush Fresh Handmade Cosmetics. 2020. Available online: https://www.lushusa.com/stories/ article_reduce-reuse-recycle.html (accessed on 16 September 2020).

60. Ongondo, F.O.; Williams, I.D.; Dietrich, J.; Carroll, C. ICT reuse in socio-economic enterprises. Waste Manag. 2013, 33, $2600-2606$. [CrossRef]

61. Greentronics. 2020. Available online: http:/ /www.greentronics.ro/ (accessed on 16 September 2020).

62. Sarc, R.; Curtis, A.; Kandlbauer, L.; Khodier, K.; Lorber, K.E.; Pomberger, R. Digitalisation and intelligent robotics in value chain of circular economy oriented waste management-A review. Waste Manag. 2019, 95, 476-492. [CrossRef] [PubMed]

63. Schilkowski, C.; Shukla, M.; Choudhary, S. Quantifying the circularity of regional industrial waste across multi-channel enterprises. Ann. Oper. Res. 2019. [CrossRef] 
64. Leba, M.; Ionica, A.; Dovleac, R.; Dobra, R. Waste management system for batteries. Sustainability 2018, 10, 332. [CrossRef]

65. Kouhizadeh, M.; Sarkis, J.; Zhu, Q. At the Nexus of Blockchain Technology, the Circular Economy, and Product Deletion. Appl. Sci. 2019, 9, 1712. [CrossRef]

66. Cao, J.; Xu, J.; Wang, H.; Zhang, X.; Chen, X.; Zhao, Y.; Yang, X.; Zhou, G.; Schnoor, J.L. Innovating collection modes for waste electrical and electronic equipment in China. Sustainability 2018, 5, 1446. [CrossRef]

67. Akinadé, O.O.; Oyedele, L.O. Integrating construction supply chains within a circular economy: An ANFIS-based waste analytics system (A-WAS). J. Clean. Prod. 2019. [CrossRef]

68. Zhang, A.; Zhong, R.Y.; Farooque, M.; Kang, K.; Venkatesh, V.G. Blockchain-based life cycle assessment: An implementation framework and system architecture. Resour. Conserv. Recycl. 2020, 152, 104512. [CrossRef]

69. Belaud, J.-P.; Prioux, N.; Vialle, C.; Sablayrolles, C. Big data for agri-food 4.0: Application to sustainability management for by-products supply chain. Comput. Ind. 2019, 111, 41-50. [CrossRef]

70. Honic, M.; Kovacic, I.; Sibenik, G.; Rechberger, H. Data- and stakeholder management framework for the implementation of BIM-based Material Passports. J. Build. Eng. 2019, 23, 341-350. [CrossRef]

71. Bai, C.; Shah, P.; Zhu, Q.; Sarkis, J. Green product deletion decisions: An integrated sustainable production and consumption approach. Ind. Manag. Data Syst. 2018. [CrossRef]

72. Nascimento, D.L.M.; Alencastro, V.; Quelhas, O.L.G.; Caiado, R.G.G.; Garza-Reyes, J.A.; Lona, L.R.; Tortorella, G. Exploring Industry 4.0 technologies to enable circular economy practices in a manufacturing context: A business model proposal. J. Manuf. Technol. Manag. 2019, 30, 607-627. [CrossRef]

73. Nespresso. Nespresso Commitments Doing Is Everything Nespresso. 2020. Available online: https://www.nespresso.com/it/it/ commitments (accessed on 16 September 2020).

74. Fraccascia, L.; Yazdanpanah, V.; van Capelleveen, G.C.; Yazan, D.M. A framework for industrial symbiosis systems for agent-based simulation. In Proceedings of the 2019 IEEE 21st Conference on Business Informatics (CBI), Moscow, Russia, 15-17 July 2019.

75. Yeo, Z.; Masi, D.; Low, J.S.C.; Yen, N.T.; Tan, P.S.; Barnes, S. Tools for promoting industrial symbiosis: A systematic review. J. Ind. Ecol. 2019. [CrossRef]

76. Raabe, B.; Low, J.S.C.; Juraschek, M.; Herrmann, C.; Tjandra, T.B.; Ng, Y.T.; Kurle, D.; Cerdas, F.; Lueckenga, J.; Yeo, Z.; et al Collaboration Platform for Enabling Industrial Symbiosis: Application of the By-product Exchange Network Model. Procedia CIRP 2017, 61, 263-268. [CrossRef]

77. Gómez, A.M.M.; González, F.A.; Bárcena, M.M. Smart eco-industrial parks: A circular economy implementation based on industrial metabolism. Resour. Conserv. Recycl. 2018, 135, 58-69. [CrossRef]

78. Cutaia, L.; Antonella, L.; Barberio, G.; Sbaffoni, S.; Mancuso, E.; Scagliarino, C.; La Monica, M. The experience of the first industrial symbiosis platform in Italy. Environ. Eng. Manag. J. 2015. [CrossRef]

79. Oltra-Badenes, R.; Gil-Gomez, H.; Guerola-Navarro, V.; Vicedo, P. Is It Possible to Manage the Product Recovery Processes in an ERP? Analysis of Functional Needs. Sustainability 2019, 11, 4380. [CrossRef]

80. Viegas, C.V.; Bond, A.; Vaz, C.R.; Bertolo, R.J. Reverse flows within the pharmaceutical supply chain: A classificatory review from the perspective of end-of-use and end-of-life medicines. J. Clean. Prod. 2019, 238, 117719. [CrossRef]

81. Chileshe, N.; Jayasinghe, R.S.; Rameezdeen, R. Information flow-centric approach for reverse logistics supply chains. Autom. Constr. 2019, 106, 102858. [CrossRef]

82. Bernon, M.; Tjahjono, B.; Ripanti, E.F. Aligning retail reverse logistics practice with circular economy values: An exploratory framework. Prod. Plan. Control 2018, 29, 483-497. [CrossRef]

83. Masi, D.; Day, S.; Godsell, J. Supply chain configurations in the circular economy: A systematic literature review. Sustainability 2017, 9, 1602. [CrossRef]

84. Rogers, Z.S.; Carter, C.R.; Kwan, V. Making tough choices: A policy capturing approach to evaluating the tradeoffs in sustainable supplier development initiatives. J. Purch. Supply Manag. 2019, 25, 100574. [CrossRef]

85. Aalirezaei, A.; Noorbakhsh, A.; Esfandi, N. Evaluation of relationships between GSCM practices and SCP using SEM approach: An empirical investigation on Iranian automobile industry. J. Remanuf. 2018. [CrossRef]

86. Liou, J.J.H.; Tamošaitiene, J.; Zavadskas, E.K.; Tzeng, G.H. New hybrid COPRAS-G MADM Model for improving and selecting suppliers in green supply chain management. Int. J. Prod. Res. 2016, 54, 114-134. [CrossRef]

87. Gan, S.-S. The Conceptual Framework of Information Technology Adoption Decision-Making in a Closed-Loop Supply Chain. In Proceeding of the International Conference on Productivity and Sustainability in Science Engineering and Technology, Jakarta, Indonesia, 5-7 December 2017; Volume 8.

88. Garrido-Hidalgo, C.; Olivares, T.; Ramirez, F.J.; Roda-Sanchez, L. An end-to-end Internet of Things solution for Reverse Supply Chain Management in Industry 4.0. Comput. Ind. 2019, 112, 103127. [CrossRef]

89. Mahadevan, K. Collaboration in reverse: A conceptual framework for reverse logistics operations. Int. J. Product. Perform. Manag. 2019. [CrossRef]

90. Akcil, A.; Agcasulu, I.; Swain, B. Valorization of waste LCD and recovery of critical raw material for circular economy: A review. Resour. Conserv. Recycl. 2019, 149, 622-637. [CrossRef]

91. Temur, G.T.; Bolat, B. Evaluating efforts to build sustainable WEEE reverse logistics network design: Comparison of regulatory and non-regulatory approaches. Int. J. Sustain. Eng. 2017. [CrossRef] 
92. Romero, D.; Molina, A. Reverse-Green Virtual Enterprises and their Breeding Environments: Closed-loop networks. In Proceedings of the IFIP Advances in Information and Communication Technology, Klagenfurt, Austria, 9-13 September 2013; Springer: New York, NY, USA, 2013; Volume 408, pp. 589-598.

93. Bahtia, M.S.; Kumar, R.S. Antecedents of implementation success in closed-loop supply chain: An empirical investigation. Int. J. Prod. Res. 2019. [CrossRef]

94. Coenena, J.; der Heijdena, R.E.C.M.; Riel, A.C.R. Understanding approaches to complexity and uncertainty in closed-loop supply chain management: Past findings and future directions. J. Clean. Prod. 2018. [CrossRef]

95. Bai, C.; Kusi-Sarpong, S.; Sarkis, J. An implementation path for green information technology systems in the Ghanaian mining industry. J. Clean. Prod. 2017, 164, 1105-1123. [CrossRef]

96. Islam, S.; Karia, N.; Fauzi, F.B.A.; Soliman, M.S.M. A review on green supply chain aspects and practices. Manag. Mark. 2017, 12, 12-36. [CrossRef]

97. Wong, C.W.Y.; Lai, K.; Lun, Y.H.V.; Cheng, T.C.E. Environmental management practices with supply chain efforts. In SpringerBriefs in Applied Sciences and Technology; Springer Nature: Berlin, Germany, 2015; pp. 29-72.

98. Agi, M. Analysis of the influence of organisational and inter-organisational factors on the implementation of Green Supply Chain Management practices. In Proceedings of the 2015 International Conference on Industrial Engineering and Systems Management (IESM), Seville, Spain, 21-23 October 2015.

99. Subramanian, N.; Gunasekaran, A. Cleaner supply-chain management practices for twenty-first-century organizational competitiveness: Practice-performance framework and research propositions. Int. J. Prod. Econ. 2015, 164, 216-233. [CrossRef]

100. Papettia, A.; Marconi, M.; Rossia, M.; Germani, M. Web-based platform for eco-sustainable supply chain management. Sustain. Prod. Consum. 2019. [CrossRef]

101. Pal, R.; Sandberg, E. Sustainable value creation through new industrial supply chains in apparel and fashion. IOP Conf. Ser. Mater. Sci. Eng. 2017, 254. [CrossRef]

102. Kalverkamp, M.; Pehlken, A.; Wuest, T.; Young, S.B. Sustainability of cascading product lifecycles: The need for adaptive management to end-of-life supply chains. In Proceedings of the IFIP Advances in Information and Communication Technology, Turin, Italy, 2-4 July 2018; Springer: New York, NY, USA, 2018; Volume 540, pp. 159-168.

103. Tseng, M.L.; Islam, M.S.; Karia, N.; Fauzi, F.A.; Afrin, S. A literature review on green supply chain management: Trends and future challenges. Resour. Conserv. Recycl. 2019, 141, 145-162. [CrossRef]

104. Philips Lighting. Light as a Service Philips Lighting. 2020. Available online: https://www.lighting.philips.co.uk/campaigns/artled-technology (accessed on 16 September 2020).

105. De Sousa Jabbour, A.B.L.; Rojas Luiz, J.V.; Rojas Luiz, O.; Jabbour, C.J.C.; Ndubisi, N.O.; Caldeira de Oliveira, J.H.; Junior, F.H. Circular economy business models and operations management. J. Clean. Prod. 2019, 235, 1525-1539. [CrossRef]

106. Xin, Y.; Ojanen, V.; Huiskonen, J. Dealing with Knowledge Management Practices in Different Product Lifecycle Phases within Product-service Systems. Procedia CIRP 2019, 83, 111-117. [CrossRef]

107. Wu, Y.; Zhu, D. Bicycle Sharing Based on PSS-EPR Coupling Model: Exemplified by Bicycle Sharing in China. Procedia CIRP 2017, 64, 423-428. [CrossRef]

108. Wiesner, S.; Freitag, M.; Westphal, I.; Thoben, K.D. Interactions between service and product lifecycle management. Procedia CIRP 2015, 30, 36-41. [CrossRef]

109. Farnioli, M.; Llshaj, A.; Lombardi, M.; Sciarretta, N.; Di Gravio, G. A BIM-based PSS approach for the management of maintenance operations of building equipment. Buildings 2019, 9, 139. [CrossRef]

110. Chen, Z.; Huang, L. Application review of LCA (Life Cycle Assessment) in circular economy: From the perspective of PSS (Product Service System). Procedia CIRP 2019, 83, 210-217. [CrossRef]

111. Apple. Environment-Apple. 2020. Available online: https://www.apple.com/lae/environment/ (accessed on 16 September 2020).

112. Hasan, S.M.M.; Rokonuzzaman, M.; Tuhin, R.A.; Salimullah, S.M.; Ullah, M.; Sakib, T.H.; Thollander, P. Drivers and barriers to industrial energy efficiency in textile industries of Bangladesh. Energies 2019, 9, 1775. [CrossRef]

113. Daú, G.; Scavarda, A.; Scavarda, L.F.; Taveira, V.J. The healthcare sustainable supply chain 4.0: The circular economy transition conceptual framework with the corporate social responsibility mirror. Sustainability 2019, 11, 3259. [CrossRef]

114. Parida, V.; Burström, T.; Visnjic, I.; Wincent, J. Orchestrating industrial ecosystem in circular economy: A two-stage transformation model for large manufacturing companies. J. Bus. Res. 2019, 101, 715-725. [CrossRef]

115. De Oliveira, S.F.; Soares, A.L. A PLM vision for circular economy. In Proceedings of the IFIP Advances in Information and Communication Technology. In Proceedings of the 18th Working Conference onVirtual Enterprises (PROVE), Vicenza, Italy, 18-20 September 2017; Springer: New York, NY, USA, 2017; Volume 506, pp. 591-602.

116. OECD. Business Models for the Circular Economy. Bus. Model Circ. Econ. 2018. [CrossRef]

117. Rosa, P.; Sassanelli, C.; Terzi, S. Circular Business Models versus Circular Benefits: An Assessment in the Waste from Electrical and Electronic Equipments Sector. J. Clean. Prod. 2019, 231, 940-952. [CrossRef]

118. Sassanelli, C.; Rosa, P.; Rocca, R.; Terzi, S. Circular economy performance assessment methods: A systematic literature review. J. Clean. Prod. 2019, 229, 440-453. [CrossRef] 